NASA/TM-2007-215024

AIAA-2007-5742

\title{
Full-Scale System for Quantifying Leakage of Docking System Seals for Space Applications
}

Patrick H. Dunlap, Jr.

Glenn Research Center, Cleveland, Ohio

Christopher C. Daniels

The University of Akron, Akron, Ohio

Bruce M. Steinetz

Glenn Research Center, Cleveland, Ohio

Arthur H. Erker, Malcolm G. Robbie, Janice L. Wasowski, and Gary J. Drlik

Analex Corporation, Brook Park, Ohio

Michael T. Tong

Glenn Research Center, Cleveland, Ohio

Nicholas Penney

Ohio Aerospace Institute, Brook Park, Ohio 


\section{NASA STI Program . . . in Profile}

Since its founding, NASA has been dedicated to the advancement of aeronautics and space science. The NASA Scientific and Technical Information (STI) program plays a key part in helping NASA maintain this important role.

The NASA STI Program operates under the auspices of the Agency Chief Information Officer. It collects, organizes, provides for archiving, and disseminates NASA's STI. The NASA STI program provides access to the NASA Aeronautics and Space Database and its public interface, the NASA Technical Reports Server, thus providing one of the largest collections of aeronautical and space science STI in the world. Results are published in both non-NASA channels and by NASA in the NASA STI Report Series, which includes the following report types:

- TECHNICAL PUBLICATION. Reports of completed research or a major significant phase of research that present the results of NASA programs and include extensive data or theoretical analysis. Includes compilations of significant scientific and technical data and information deemed to be of continuing reference value. NASA counterpart of peer-reviewed formal professional papers but has less stringent limitations on manuscript length and extent of graphic presentations.

- TECHNICAL MEMORANDUM. Scientific and technical findings that are preliminary or of specialized interest, e.g., quick release reports, working papers, and bibliographies that contain minimal annotation. Does not contain extensive analysis.

- CONTRACTOR REPORT. Scientific and technical findings by NASA-sponsored contractors and grantees.
- CONFERENCE PUBLICATION. Collected papers from scientific and technical conferences, symposia, seminars, or other meetings sponsored or cosponsored by NASA.

- SPECIAL PUBLICATION. Scientific, technical, or historical information from NASA programs, projects, and missions, often concerned with subjects having substantial public interest.

- TECHNICAL TRANSLATION. Englishlanguage translations of foreign scientific and technical material pertinent to NASA's mission.

Specialized services also include creating custom thesauri, building customized databases, organizing and publishing research results.

For more information about the NASA STI program, see the following:

- Access the NASA STI program home page at http://www.sti.nasa.gov

- E-mail your question via the Internet to help@sti.nasa.gov

- Fax your question to the NASA STI Help Desk at 301-621-0134

- Telephone the NASA STI Help Desk at 301-621-0390

- Write to: NASA Center for AeroSpace Information (CASI) 7115 Standard Drive Hanover, MD 21076-1320 


\section{Full-Scale System for Quantifying Leakage of Docking System Seals for Space Applications}

Patrick H. Dunlap, Jr.

Glenn Research Center, Cleveland, Ohio

Christopher C. Daniels

The University of Akron, Akron, Ohio

Bruce M. Steinetz

Glenn Research Center, Cleveland, Ohio

Arthur H. Erker, Malcolm G. Robbie, Janice L. Wasowski, and Gary J. Drlik

Analex Corporation, Brook Park, Ohio

Michael T. Tong

Glenn Research Center, Cleveland, Ohio

Nicholas Penney

Ohio Aerospace Institute, Brook Park, Ohio

Prepared for the

43rd Joint Propulsion Conference and Exhibit

cosponsored by the AIAA, ASME, SAE, and ASEE

Cincinnati, Ohio, July 8-11, 2007

National Aeronautics and

Space Administration

Glenn Research Center

Cleveland, Ohio 44135 


\section{Acknowledgments}

The authors would like to thank James Lewis and the LIDS team from NASA JSC for their support on this project.

Trade names and trademarks are used in this report for identification only. Their usage does not constitute an official endorsement, either expressed or implied, by the National Aeronautics and Space Administration.

Level of Review: This material has been technically reviewed by technical management.

Available from

NASA Center for Aerospace Information 7115 Standard Drive

Hanover, MD 21076-1320
National Technical Information Service 5285 Port Royal Road Springfield, VA 22161 


\title{
Full-Scale System for Quantifying Leakage of Docking System Seals for Space Applications
}

\author{
Patrick H. Dunlap, Jr. \\ National Aeronautics and Space Administration \\ Glenn Research Center \\ Cleveland, Ohio 44135 \\ Christopher C. Daniels \\ The University of Akron \\ Akron, Ohio 44325-3901 \\ Bruce M. Steinetz \\ National Aeronautics and Space Administration \\ Glenn Research Center \\ Cleveland, Ohio 44135 \\ Arthur H. Erker, Malcolm G. Robbie, Janice L. Wasowski, and Gary J. Drlik \\ Analex Corporation \\ Brook Park, Ohio 44135 \\ Michael T. Tong \\ National Aeronautics and Space Administration \\ Glenn Research Center \\ Cleveland, Ohio 44135 \\ Nicholas Penney \\ Ohio Aerospace Institute \\ Brook Park, Ohio 44142
}

\begin{abstract}
NASA is developing a new docking and berthing system to support future space exploration missions to lowEarth orbit, the Moon, and Mars. This mechanism, called the Low Impact Docking System, is designed to connect pressurized space vehicles and structures. NASA Glenn Research Center is playing a key role in developing advanced technology for the main interface seal for this new docking system. The baseline system is designed to have a fully androgynous mating interface, thereby requiring a seal-on-seal configuration when two systems mate. These seals will be approximately $147 \mathrm{~cm}$ (58 in.) in diameter. NASA Glenn has designed and fabricated a new test fixture which will be used to evaluate the leakage of candidate full-scale seals under simulated thermal, vacuum, and engagement conditions. This includes testing under seal-on-seal or seal-on-plate configurations, temperatures from -50 to $50{ }^{\circ} \mathrm{C}$ (-58 to $122{ }^{\circ} \mathrm{F}$ ), operational and pre-flight checkout pressure gradients, and vehicle misalignment $( \pm 0.381 \mathrm{~cm}(0.150$ in. $))$ and gapping (up to $0.10 \mathrm{~cm}(0.040$ in. $))$ conditions. This paper describes the main design features of the test rig and techniques used to overcome some of the design challenges.
\end{abstract}

\section{Introduction}

\section{A. Low Impact Docking System}

In January 2004, President George W. Bush announced the new Vision for Space Exploration for NASA. ${ }^{1}$ To implement this vision, NASA's Constellation Program is developing an architecture of vehicles that will be used for future missions to the International Space Station (ISS), the Moon, and Mars. This includes the human-rated Crew Exploration Vehicle (CEV) and Lunar Surface Access Module (LSAM) as well as a collection of launch and transfer vehicles and future destination surface systems. 
To enable in-space assembly and rendezvous of these various vehicles, NASA is developing the Low Impact Docking System ${ }^{2}$ (LIDS) (Fig. 1). The LIDS mating system will be an improvement over existing docking systems in that it eliminates the need for high velocity docking, supports low velocity berthing assembly, and provides a standard interface that is modular and easily reconfigurable to support a wide range of crewed and autonomous vehicle mating and assembly operations. The baseline LIDS is designed to be a fully androgynous mating interface that can structurally connect with replicates of itself, although some implementations of LIDS for specific missions may not be completely androgynous.

The LIDS project is being led by NASA Johnson Space Center (JSC), but other NASA centers are contributing to the successful development of this new docking system.

\section{B. Main Interface Seals}

NASA Glenn Research Center (GRC) is supporting NASA JSC by developing advanced technology for the main interface seals for the top of the LIDS tunnel (Fig. 2). During docking and berthing, these seals are compressed by the LIDS hard capture system which is composed of a series of latches and tabs on each LIDS that pull the two systems toward each other and clamp them together. Once the seals are compressed, a low-leakage interface is formed between the two systems to help contain breathable air inside the mated vehicles during a mission.

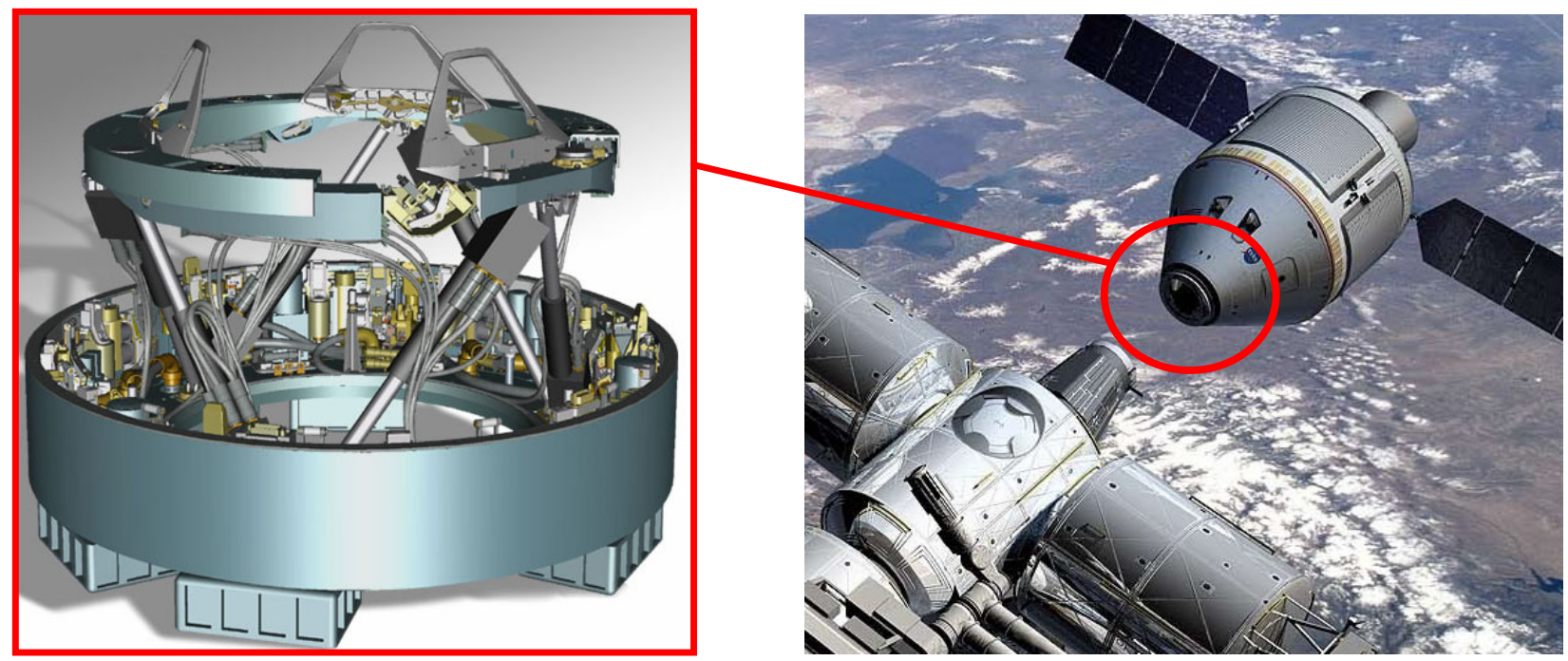

Figure 1.-LIDS model (left) and location on CEV (right) as it prepares to dock to the ISS.

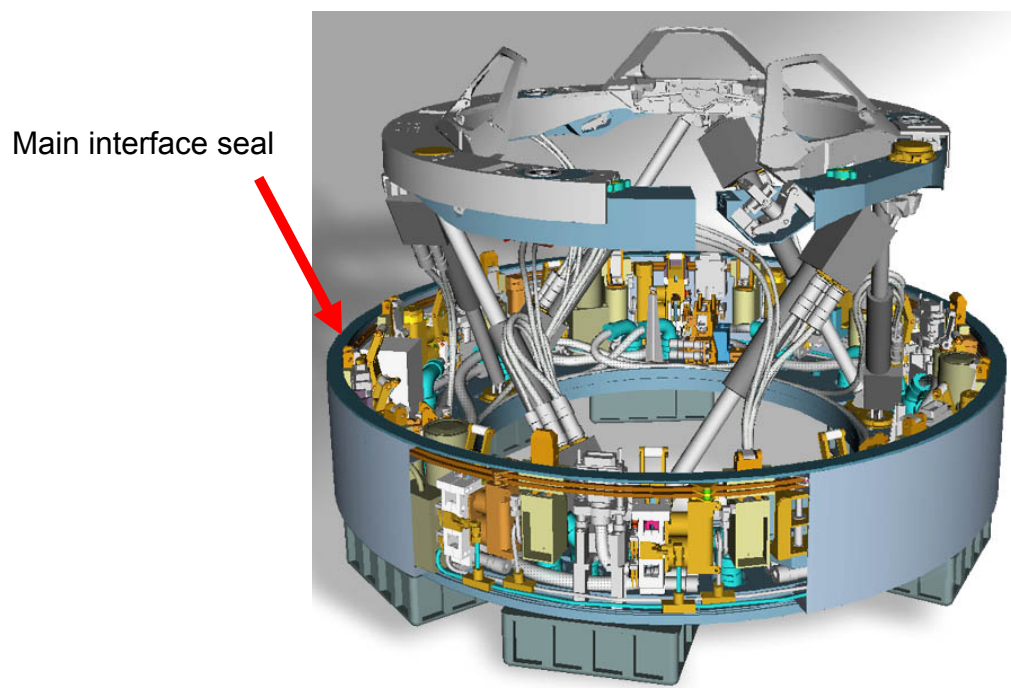

Figure 2.-Location of LIDS main interface seal. 
GRC is developing and evaluating several different seal designs to meet the requirements for the LIDS main interface seal. The baseline design is a Gask-O-Seal ${ }^{\mathrm{TM}}$ produced by Parker Hannifin Corporation (Fig. 3). ${ }^{3}$ The Gask-O-Seals that GRC is evaluating are formed by molding silicone elastomer seal bulbs directly into the grooves of an aluminum retainer. This design has a space flight pedigree and is used as a static seal on the Common Berthing Mechanism (CBM) for the ISS. ${ }^{4}$

An early prototype seal design that GRC has developed and will be evaluating is one referred to as a "gasket seal" (Fig. 4). In this design, silicone gaskets with a square cross section are bonded into a pair of grooves on the top surface of an aluminum retainer. Silicone O-rings are then installed into a corresponding pair of grooves on the bottom of the retainer. This design was developed at full-scale to be used as a temporary checkout seal for JSC's $137 \mathrm{~cm}$ (54 in.) diameter Engineering Demonstration Unit (EDU 54) and for testing at GRC while full-scale GaskO-Seals with long lead times were being fabricated.

In addition to the Gask-O-Seal and gasket seal designs, GRC conceived other promising designs that are in the very early stages of development. These designs are being discussed with vendors to begin fabricating them for evaluation at GRC.

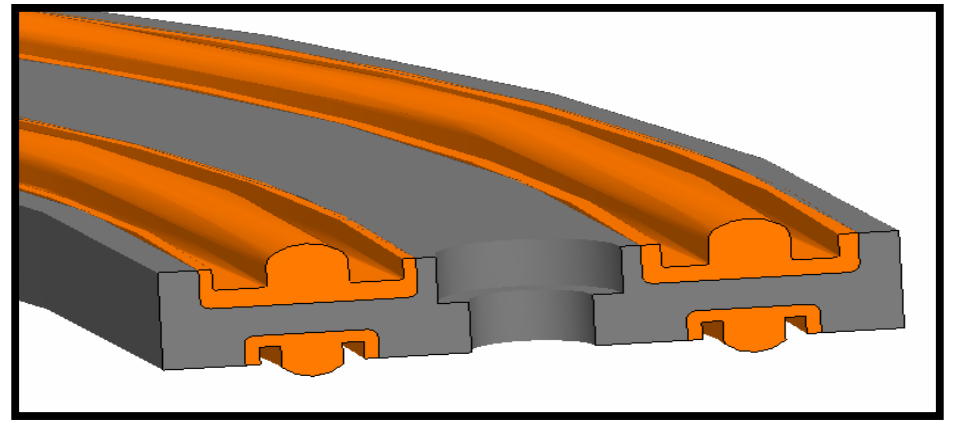

Figure 3.- Solid model of Gask-O-Seal showing silicone seals molded into grooves on top and bottom surfaces of aluminum retainer.

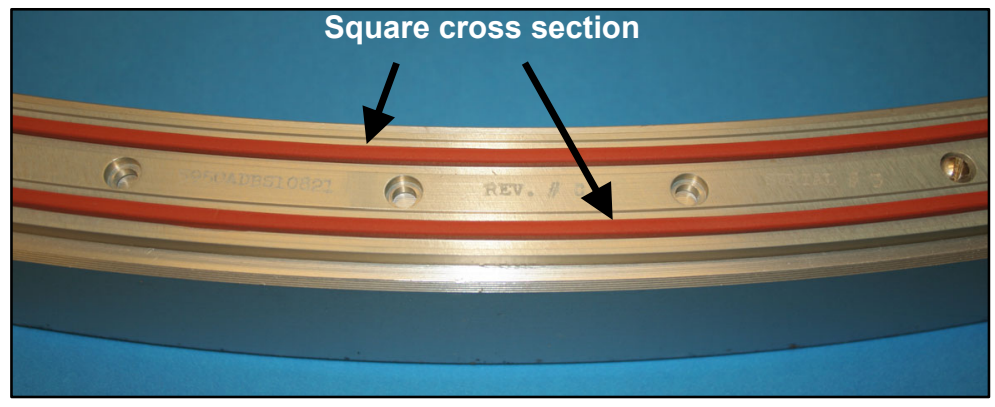

(a)

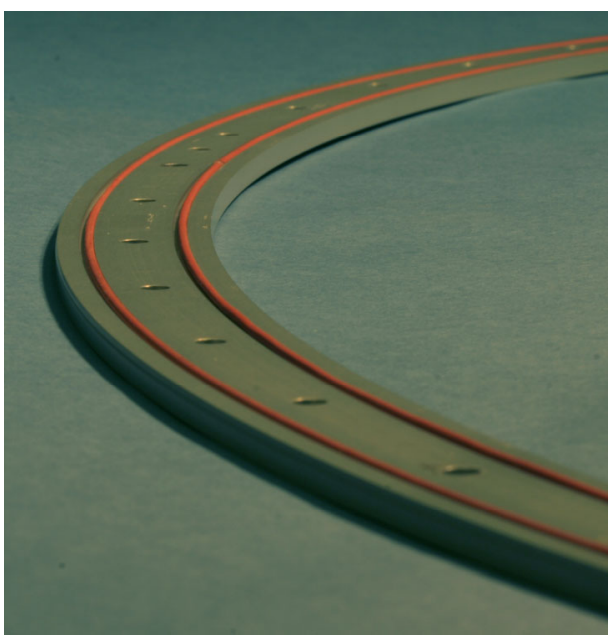

(b)

Figure 4.-Photographs of EDU 54 gasket seal showing (a) silicone gaskets with square cross sections bonded into grooves in top surface of aluminum retainer and (b) silicone O-rings installed in grooves in bottom surface of retainer. 


\section{Main Interface Seal Requirements}

\section{Leakage Rates}

The most important requirement for the LIDS main interface seals is to minimize leakage through the interface between two mated systems. Leakage rates less than $0.0045 \mathrm{~kg}$ of air per day $(0.01 \mathrm{lbm} /$ day $)$ are desired at this interface to ensure that the astronauts have sufficient breathable air for potentially long missions to the ISS, the Moon, and Mars. This can be quite a challenge for these seals given the many other requirements that have been imposed on them.

\section{Environments}

When LIDS is in an unmated state during a mission, the main interface seals will be exposed to the environment in space for potentially long periods of time. Depending on the type of mission, that environment could be low Earth orbit (LEO), orbit around the Moon or Mars, the lunar or Martian surfaces, or transit to or from the Moon or Mars. Each of these environments presents conditions that may be detrimental to the performance of the main interface seals. Exposure to ultraviolet and ionizing radiation will be a concern in all of these environments as well as potential impacts from micrometeoroids. In LEO, the seals will also be exposed to atomic oxygen and impacts from orbital debris. While on the surfaces of the Moon or Mars, the seals will also have to contend with the possible deposition of lunar or Martian dust on them.

After being exposed to all of these challenging environments, the seals will have to allow two LIDS to mate and then exhibit very little leakage from the pressurized habitat inside of LIDS to the hard vacuum of space surrounding the vehicles. The nominal internal pressure that the seals will have to seal against is $101 \mathrm{kPa}$ (14.7 psia), and the maximum internal pressure is currently $109 \mathrm{kPa}(15.8 \mathrm{psia})$ based on the maximum design pressure for the CEV.

While the temperatures of structures in space can vary greatly depending on their orientation and proximity to the sun, LIDS seal operating temperatures have been set as -50 to $50{ }^{\circ} \mathrm{C}\left(-58\right.$ to $\left.122{ }^{\circ} \mathrm{F}\right)$. Based on their orientation before mating, there are several possible thermal scenarios that could occur:

1. If both seals are facing the sun before they dock, they could both be heated to $50{ }^{\circ} \mathrm{C}$.

2. If both seals are facing away from the sun before they dock, they could both be cooled to $-50{ }^{\circ} \mathrm{C}$.

3. If one seal is facing toward the sun and the other is facing away from it, they could reach 50 and $-50{ }^{\circ} \mathrm{C}$, respectively.

4. If both LIDS seals are facing perpendicular to the sun before they dock, half of each seal could be heated and the other half cooled.

Overall, the LIDS main interface seals must withstand long term exposure to all of these environments without excessive damage or significant loss of sealing ability.

\section{Loads}

When the LIDS hard capture system pulls together two LIDS during the final stages of docking or berthing, the main interface seals will generate compressive loads that the latches must overcome. To stay within the capabilities of the latch mechanisms, the seal loads must stay below a prescribed limit so as not to overload the latches. When it comes time for the two LIDS to undock, the main interface seals must exhibit very low adhesion forces to allow the two systems to separate. If the seals were too adhesive, the ability of the systems to undock could be restricted.

\section{Mating Configurations}

As noted earlier, the baseline configuration for LIDS includes a fully androgynous mating interface. This means that every copy of LIDS would have a main interface seal on top of the LIDS tunnel, and a seal-on-seal configuration would result when two systems mate (Fig. 5(a)). This presents a challenge for the main interface seals because seals are usually compressed against flat, smooth surfaces instead of against other seals. Adding to this challenge is the requirement that the seals exhibit extremely low leakage rates. To accomplish this in a seal-on-seal configuration, the seals on each LIDS must align with each other very precisely to form an effective, low-leakage joint.

An alternative configuration that is being considered for some missions would have a seal on one LIDS and a flat, smooth metal plate in place of the seal on the other one. This would result in "seal-on-plate" mating at the sealing interface (Fig. 5(b)). Configurations such as this may be utilized for missions in which a LIDS would be exposed to the space environment for many years resulting in degradation of the seals and subsequent increases in seal leakage. 


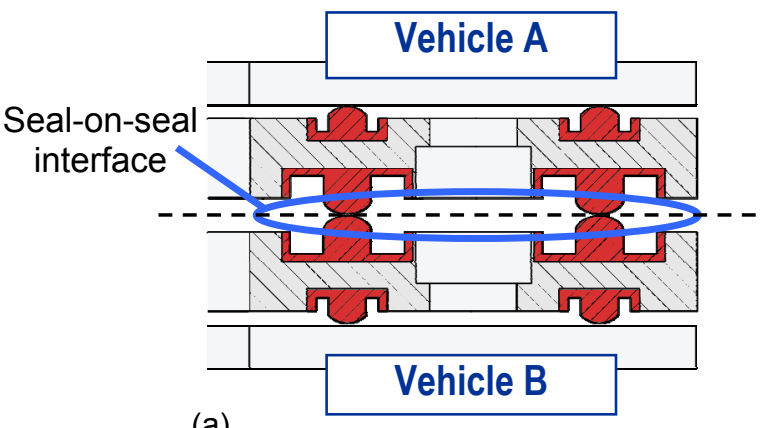

(a)

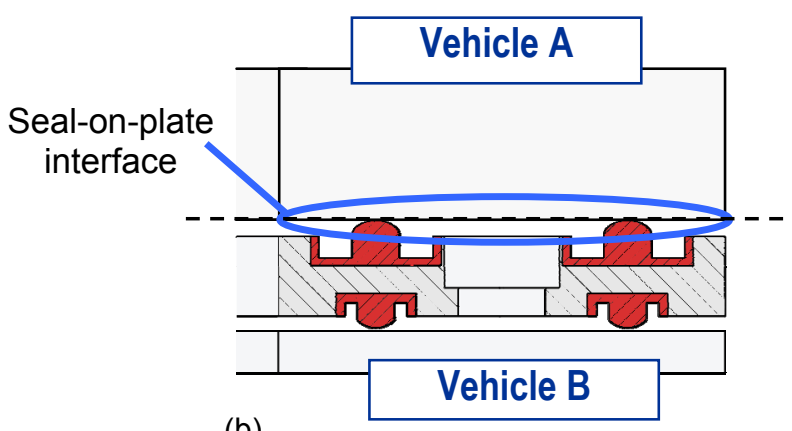

(b)

Figure 5.-Cross sections through the interface between two mated LIDS showing (a) seal-on-seal interface and (b) seal-on-plate interface.

One scenario where a seal-on-plate configuration may be employed would be for CEV missions to the ISS. The main interface seal location on the LIDS on the ISS will be exposed to the environment in LEO for long periods of time when nothing is docked to it. To address this issue, a seal would be employed on the LIDS on the CEV, and a flat plate would be used on the LIDS on the ISS. Replacing the seal on the ISS with a much more durable, flat metal plate would greatly reduce degradation of this sealing surface after long exposures in LEO.

\section{Vehicle Alignment/Misalignment}

Because LIDS is a large structure composed of many complex subsystems and parts, the main interface seals on each LIDS will not be perfectly aligned with each other when two LIDS systems mate. There are several sources of this misalignment:

1. Multiple subsystems involved in bringing two LIDS together to compress the seals,

2. Difficulties in fabricating large pieces of hardware with very tight tolerances,

3. Tolerance stackups of multiple parts involved in the docking/berthing process including latches on an active LIDS and tabs on its passive mate (i.e., alignment pins and slots).

There are two types of misalignment that the main interface seals must overcome: gapping (Fig. 6) and radial offsets (Fig. 7). The LIDS hard capture system is designed to bring two main interface seals completely into contact with each other. Under normal docking conditions, the main interface seals are fully compressed, and metal-to-metal contact occurs between the two seal retainers. However, scenarios may arise which lead to "gapping" between the two seal retainers where the LIDS hard capture system does not achieve metal-to-metal contact. These scenarios include: (1) an incomplete docking where the latching system fails to fully seat the seals, and (2) in-flight conditions where transient dynamic loads cause the LIDS-to-LIDS interface to open momentarily. Gapping can occur either as a uniform gap around the perimeter of the seals or as an angled gap such that the retainers are in contact in one location and are separated by a progressively larger gap up to $180^{\circ}$ from the point of contact. For preliminary design purposes, designers are assuming that gaps as large as $0.10 \mathrm{~cm}(0.040 \mathrm{in}$.) may occur.

One of the main sources of radial offset between seals is the misalignment between tunnel centerlines during mating. This can be as large as $\pm 0.15 \mathrm{~cm}$ ( \pm 0.060 in.) due to the manufacturing tolerances in the tunnel-to-tunnel centering pins and slots. Another potentially large source of radial offset is a temperature difference between mating LIDS systems. For example, if one LIDS is at $-50{ }^{\circ} \mathrm{C}\left(-58^{\circ} \mathrm{F}\right)$ and the other one is at $50{ }^{\circ} \mathrm{C}\left(122^{\circ} \mathrm{F}\right)$, two seals whose diameters were initially $147 \mathrm{~cm}$ (58 in.) can vary in diameter by as much as $0.348 \mathrm{~cm}(0.137 \mathrm{in}$.) due to differential thermal growths. Thus a temperature difference between seals of $100{ }^{\circ} \mathrm{C}\left(180{ }^{\circ} \mathrm{F}\right)$ can result in offsets on the order of $\pm 0.17 \mathrm{~cm}$ ( \pm 0.068 in.). Other sources of misalignment include tolerances on: seal bead width and position within the seal retainer, interfaces between mating seals, and interfaces between the seals and the tunnel flanges to which they are attached. These contribute as much as $\pm 0.051 \mathrm{~cm}( \pm 0.020 \mathrm{in}$.) to the total amount of offset. When all of these misalignments are combined, a total radial offset of up to $\pm 0.381 \mathrm{~cm}( \pm 0.150$ in.) could result.

The LIDS main interface seals must be able to form an effective, low-leakage seal under both nominal and offnominal alignment conditions. 


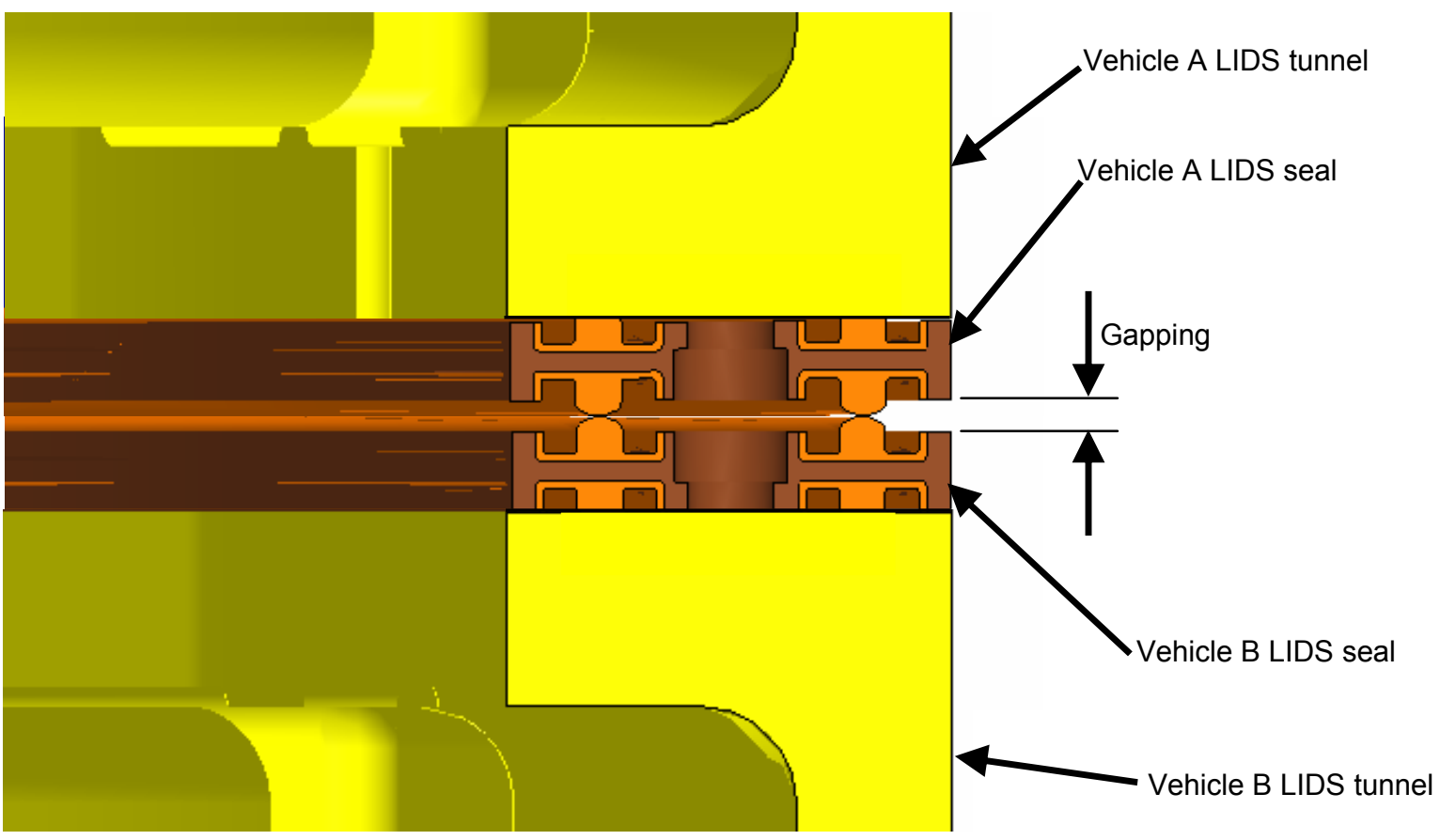

Figure 6.-Gapping between mated main interface seals.

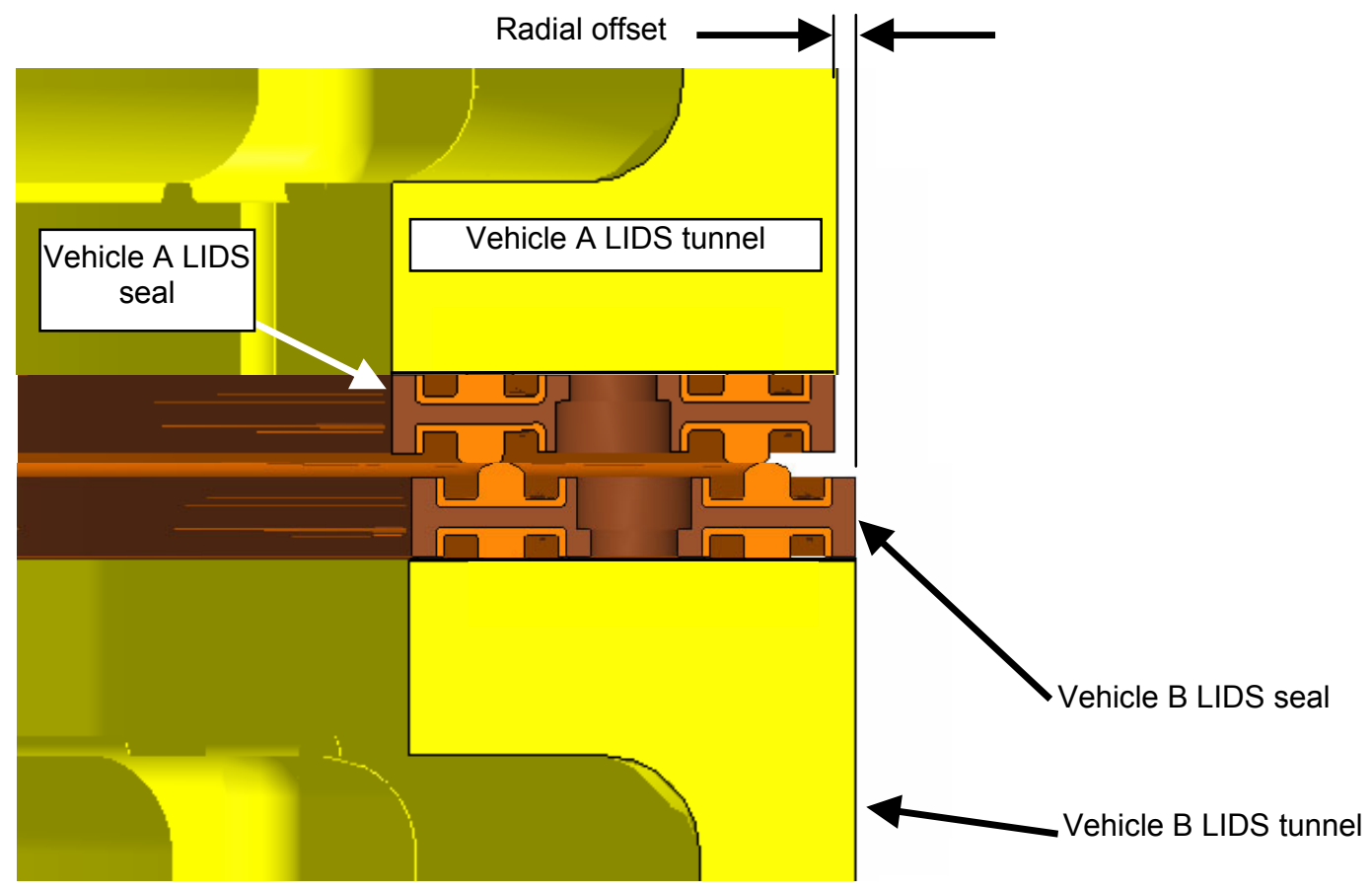

Figure 7._-Radial offset between mated interface seals. 


\section{Test Rig Design Goals and Requirements}

\section{A. Primary Goal}

The previous section provided an overview of the requirements for the LIDS main interface seals. GRC is developing a new test rig to measure the leakage of candidate full-scale seals under anticipated operating conditions. Table 1 summarizes the seal requirements in terms of how they apply to the design of the new test rig.

TABLE 1.--LIDS MAIN INTERFACE SEAL REQUIREMENTS AS THEY APPLY TO FULL-SCALE TEST RIG DESIGN.

\begin{tabular}{|c|c|c|}
\hline Parameter & Units & Requirement \\
\hline \multicolumn{3}{|l|}{ Physical Characteristics } \\
\hline Outer diameter & $\mathrm{cm}$ (in.) & $137-147(54-58)$ \\
\hline Configuration & --- & Continuous ring \\
\hline Retainer thickness (i.e., thickness when fully compressed) & $\mathrm{cm}$ (in.) & $0.51(0.20)$ \\
\hline Maximum face width & $\mathrm{cm}$ (in.) & $3.81(1.50)$ \\
\hline Alignment of seal to tunnel & --- & 3 precision pins at $120^{\circ}$ \\
\hline \multicolumn{3}{|l|}{ Interface Characteristics } \\
\hline Flatness of LIDS flange & $\mathrm{cm}$ (in.) & $0.010(0.004)(\mathrm{TBR})^{*}$ \\
\hline Maximum surface roughness of sealing surfaces (e.g., LIDS flange) & $\mu \mathrm{m}$ ( $\mu$ in.) & $0.41(16)(\mathrm{TBR})$ \\
\hline \multicolumn{3}{|l|}{ Performance Characteristics } \\
\hline \multicolumn{3}{|l|}{ Temperatures } \\
\hline Maximum operational temperature & ${ }^{\circ} \mathrm{C}\left({ }^{\circ} \mathrm{F}\right)$ & $50(122)$ \\
\hline Minimum operational temperature & ${ }^{\circ} \mathrm{C}\left({ }^{\circ} \mathrm{F}\right)$ & $-50(-58)$ \\
\hline Maximum temperature gradient around circumference & ${ }^{\circ} \mathrm{C}\left({ }^{\circ} \mathrm{F}\right)$ & $16(29)^{5}$ \\
\hline \multicolumn{3}{|l|}{ Pressure: Operational } \\
\hline External pressure & $\mathrm{kPa}(\mathrm{psia})$ & 0 (hard vacuum of space) \\
\hline Nominal internal pressure & $\mathrm{kPa}(\mathrm{psia})$ & $101(14.7)$ \\
\hline Maximum internal pressure & $\mathrm{kPa}(\mathrm{psia})$ & $109(15.8)$ \\
\hline \multicolumn{3}{|l|}{ Pressure: Pre-flight Checkout } \\
\hline Differential pressure across seals & $\mathrm{kPa}$ (psid) & $101(14.7)$ \\
\hline \multicolumn{3}{|l|}{ Loads } \\
\hline Maximum seal compressive load & $\begin{array}{l}\text { N per cm of seal bulb per } \\
\text { seal (lbf per inch of seal } \\
\text { bulb per seal) }\end{array}$ & $175+(100+)$ \\
\hline Maximum load to separate seals & $\mathrm{N}(\mathrm{lbf})$ & Low - TBD \\
\hline \multicolumn{3}{|l|}{ Off-Nominal Docking Engagement Conditions } \\
\hline Tunnel-to-tunnel axis misalignment & $\mathrm{cm}$ (in.) & $\pm 0.15( \pm 0.060)$ \\
\hline Thermal misalignments & $\mathrm{cm}$ (in.) & $\pm 0.17( \pm 0.068)$ \\
\hline Other manufacturing and assembly tolerances & $\mathrm{cm}$ (in.) & $\pm 0.051( \pm 0.020)$ \\
\hline Angled gap & $\mathrm{cm}$ (in.) & $0.10(0.040)$ \\
\hline Uniform gap & $\mathrm{cm}$ (in.) & $0.10(0.040)$ \\
\hline
\end{tabular}

* TBR = To Be Revised

\section{B. Test Rig Requirements}

\section{Seal-on-Seal Versus Seal-on-Plate Testing}

Because the baseline LIDS is designed to have a fully androgynous mating interface, the test rig must be able to evaluate seals in a seal-on-seal configuration. However, it has also been noted that some implementations of LIDS for specific missions may not be completely androgynous. Therefore, in addition to being able to test seals in a sealon-seal configuration, the test rig must be able to perform tests in a seal-on-plate configuration. 


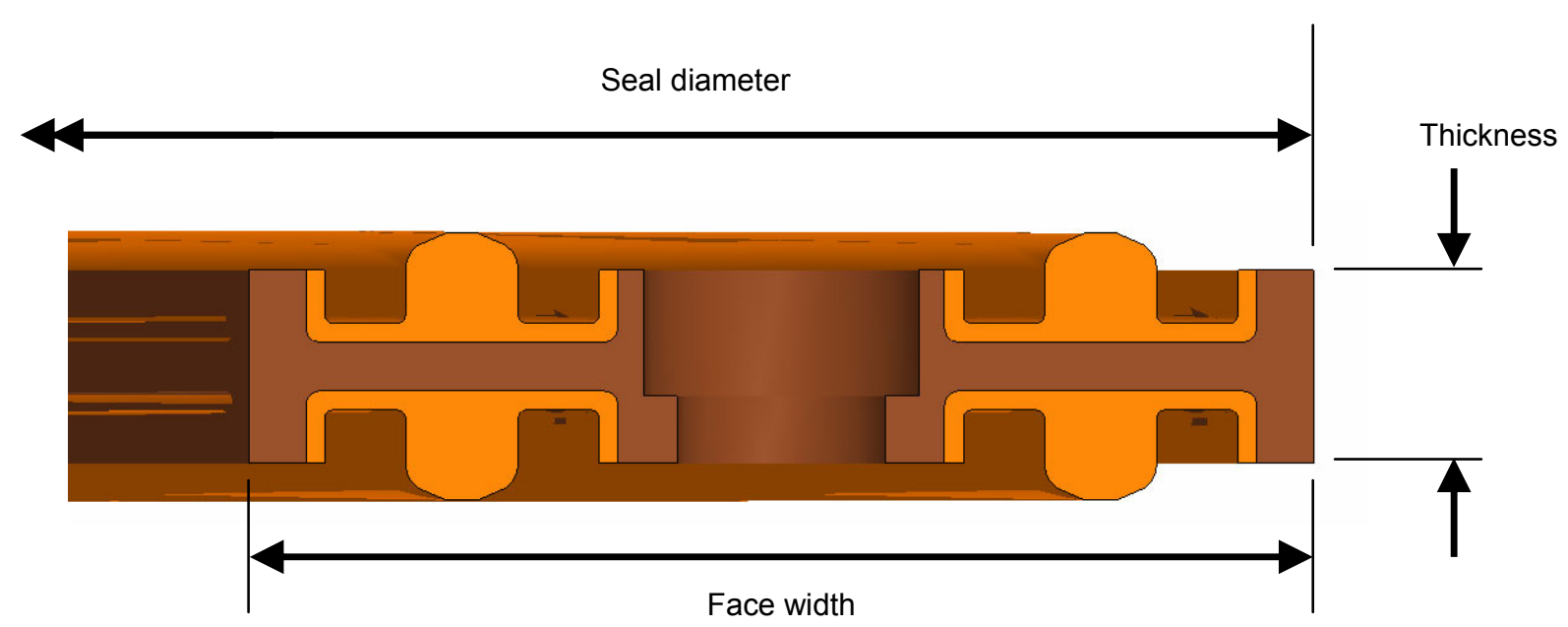

Figure 8.-LIDS main interface seal geometry terminology.

\section{Different Seal Sizes and Designs}

The test rig must be able to evaluate seals of different sizes including diameters ranging from 132 to $152 \mathrm{~cm}$ (52 to 60 in.) (Fig. 8). This range encompasses $137 \mathrm{~cm}$ (54 in.) diameter seals for the LIDS EDU 54, $147 \mathrm{~cm}$ (58 in.) diameter seals for the LIDS Engineering Demonstration Unit 58 (EDU 58), and planned $147 \mathrm{~cm}$ (58 in.) diameter seals for future LIDS flight units.

Seal designs with various cross sections are also being developed. The baseline thickness for fully compressed seals is currently set at $0.51 \mathrm{~cm}(0.20 \mathrm{in}$.), but future seals for missions to the Moon and Mars may be thicker. The face width of the EDU 54 seals is $2.86 \mathrm{~cm}$ (1.13 in.), and the width of seals for the EDU 58 will be $3.81 \mathrm{~cm}$ (1.50 in.). The test rig must be able to evaluate all candidate seal designs.

\section{Thermal Conditions}

The test rig must be able to heat and cool the seal test specimens to simulate the thermal conditions that they would experience during a mission. This includes all of the various scenarios that were noted earlier:

1. Both seals heated to $50^{\circ} \mathrm{C}\left(122^{\circ} \mathrm{F}\right)$,

2. Both seals cooled to $-50^{\circ} \mathrm{C}\left(-58^{\circ} \mathrm{F}\right)$,

3. One seal heated to $50{ }^{\circ} \mathrm{C}$ and the other one cooled to $-50{ }^{\circ} \mathrm{C}$,

4. Half of each seal heated and the other half cooled.

The test rig must be able to heat and cool each seal independently to generate all of these test conditions. Given that the rig must be capable of performing tests at temperatures as low as $-50{ }^{\circ} \mathrm{C}$, provisions must be included in the design to prevent condensation and ice from accumulating on the hardware during testing.

\section{Pressure Conditions}

The test rig must be able to generate pressure differentials across the seals to simulate LIDS operating conditions in space and pre-flight checkout conditions on the ground. The nominal pressure differential across the seals would occur when the CEV is docked to the ISS. In this case, the inner diameter of the seals would be pressurized to $101 \mathrm{kPa}(14.7 \mathrm{psia})$, and the outer diameter of the seals would experience the hard vacuum of space. To simulate these conditions, the test rig must be able to generate a pressure of at least $101 \mathrm{kPa}$ in the cavity inboard of the inner diameter of the seals while pulling a vacuum around the outer perimeter of the seals.

Pre-flight checkout tests will also be performed on the seals before a launch to ensure that they are installed correctly and meeting the appropriate leakage requirements. During these tests, the inner diameter of the seals will be pressurized to $203 \mathrm{kPa}$ (29.4 psia) with ambient pressure around the outer perimeter of the seals to set up the same pressure differential that would be experienced in space. 


\section{Engagement Conditions}

The test rig must be able to evaluate the seals in both aligned and misaligned configurations. Provisions are required to test radial offsets between mating seals of at least $0.381 \mathrm{~cm}(0.150 \mathrm{in}$.). The rig must also be capable of testing seals in the fully compressed condition and with angled and uniform gaps up to $0.10 \mathrm{~cm}(0.040 \mathrm{in}$.).

\section{Instrumentation}

The test rig must be instrumented to record data during testing. Since the most important requirement for the main interface seals is to minimize leakage through the interface between two mated LIDS, leakage measurements must be made for each type of test that is to be performed. Pressure transducers shall be included to measure the pressure differential across the seals for both seal pressurization scenarios: LIDS operating conditions in space and pre-flight checkout conditions on the ground. Thermocouples shall also be included to measure the temperature distribution around each seal during testing.

Health monitoring instrumentation is also vital to the functionality of the test rig. Instrumentation must be provided where appropriate to ensure that pressures and temperatures in the test rig stay within predetermined safe ranges.

\section{Test Rig Design and Attributes}

Figures 9 and 10 show the main elements of a test rig designed to meet the aforementioned requirements for fullscale LIDS main interface seal testing. This test rig is capable of evaluating the complete range of candidate seal sizes and designs under seal-on-seal or seal-on-plate conditions. Tests can be performed under the desired thermal, pressure, and engagement conditions. Instrumentation is located throughout the test rig to quantify seal performance during testing and to monitor the health of the test rig. The following sections describe how the design goals were met for this test rig.

\section{A. Seal Plate Assemblies}

The heart of the test rig is a pair of seal plate assemblies that hold the seal test specimens during testing (Fig. 10). Each assembly is composed of a seal cartridge, inner and outer filler rings, and a pair of hot/cold plates (Fig. 11). Sets of alignment pins and gapping spacers are installed into the seal plate assemblies to achieve various levels of seal misalignment and gapping.

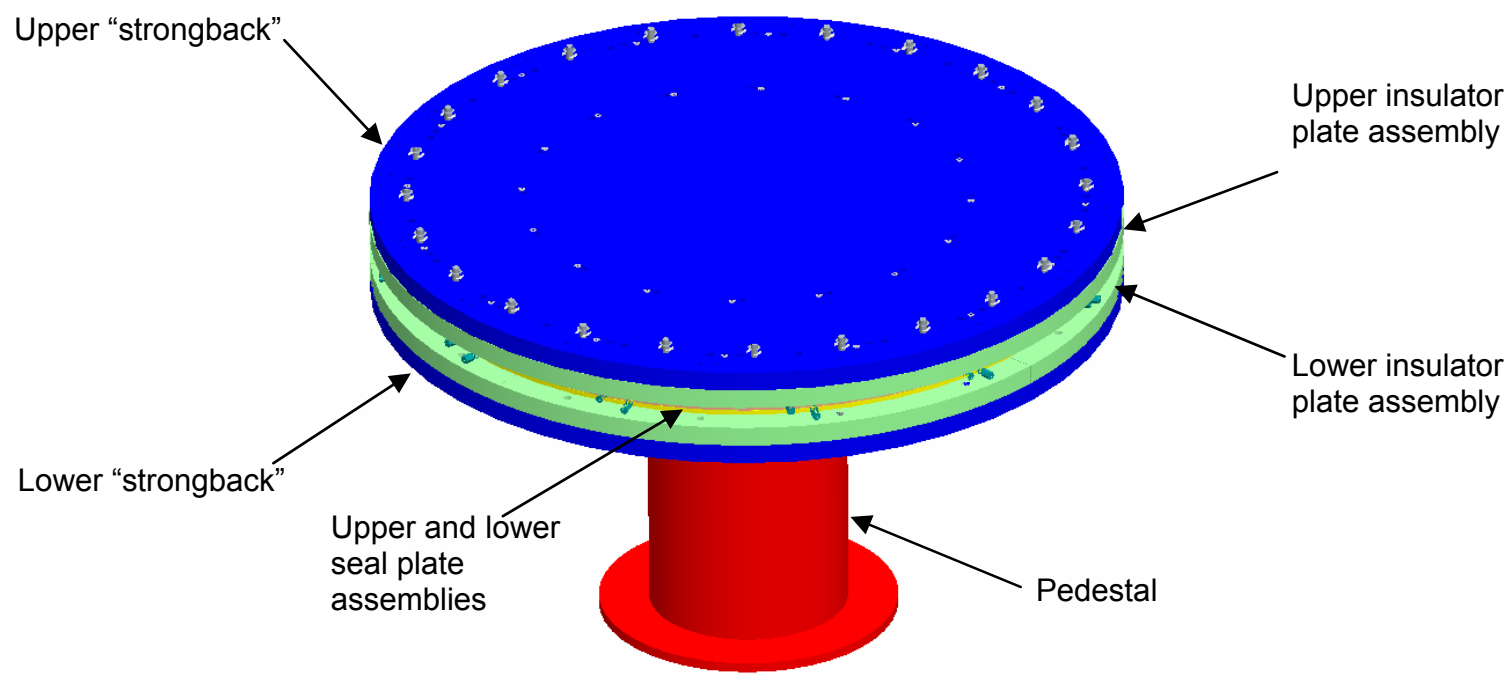

Figure 9.-Main elements of the full-scale LIDS seal test rig. 


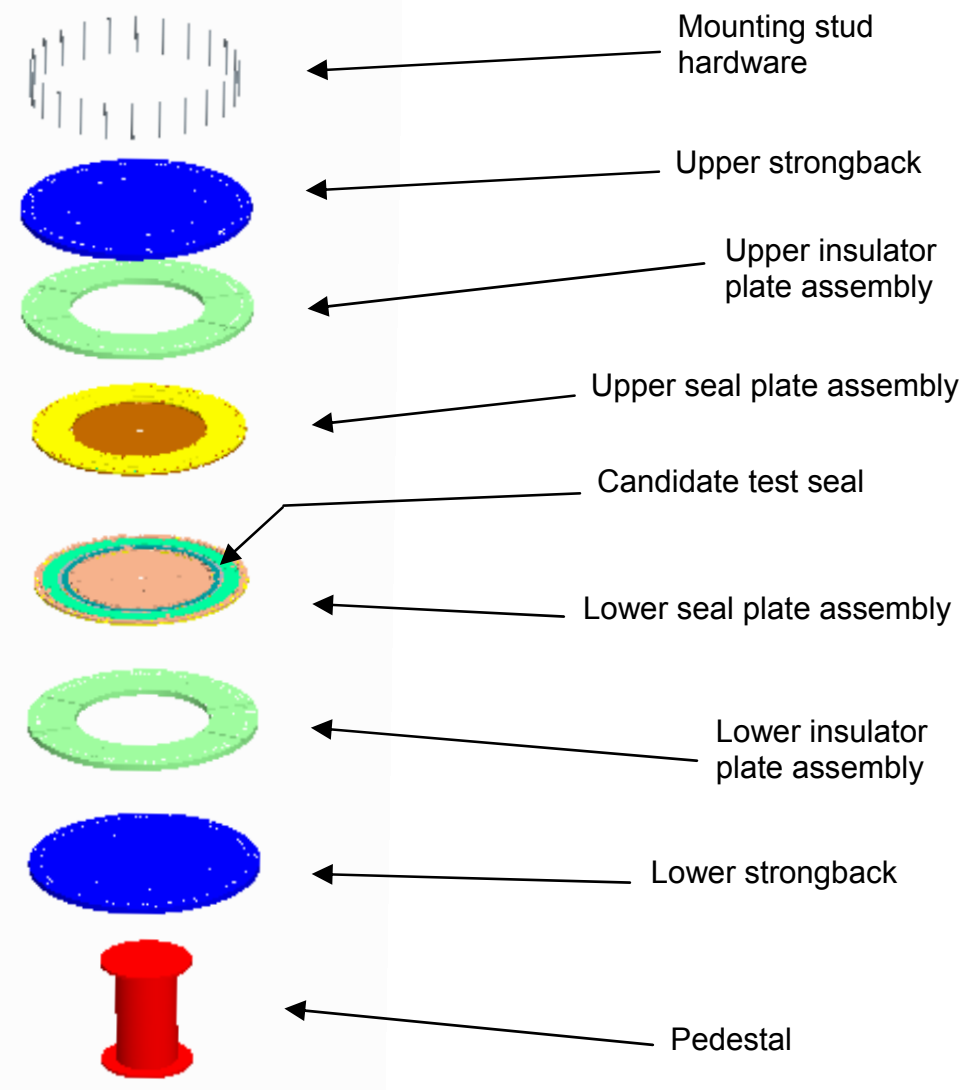

Figure 10.-Exploded view of main elements of the full-scale LIDS seal test rig.

\section{Modular Seal Cartridges}

To accommodate the variety of candidate seal sizes and designs that are to be evaluated, a modular seal cartridge was designed (Fig. 12). The top surface of the seal cartridge contains a wide, annular pocket with an inner diameter of $121.0 \mathrm{~cm}(47.63 \mathrm{in}$.$) and an outer diameter of 163.8 \mathrm{~cm}(64.50 \mathrm{in}$.$) to accept seals with outer diameters ranging$ from 132 to $152 \mathrm{~cm}(52$ to 60 in.). Although test plans currently only call for $137 \mathrm{~cm}(54 \mathrm{in}$.) and $147 \mathrm{~cm}(58 \mathrm{in}$.) seals to be tested, provisions were included to test slightly larger and smaller seals in case the size of the LIDS main interface seal changes in the future.

The oversized annular pocket also allows a broad range of seal widths to be tested including current seal designs for the EDU 54 and EDU 58 that are $2.86 \mathrm{~cm}$ (1.13 in.) and $3.81 \mathrm{~cm}$ (1.50 in.) wide, respectively. Even wider seals can also be tested in the oversized pocket of the seal cartridge. The depth of the pocket is currently sized to test seals that are $0.51 \mathrm{~cm}(0.20 \mathrm{in}$.) thick, but other seal thicknesses can be evaluated by modifying the seal cartridge design slightly and fabricating additional cartridges with deeper or shallower pockets.

When a test seal is installed into the seal cartridge, three alignment pins are used to hold the seal coaxial to the centerline of the seal plate assembly to within $0.008 \mathrm{~cm}(0.003 \mathrm{in}$.). Once the test seal is located by the three alignment pins, it is secured to the seal cartridge by 72 fasteners to hold it in place during testing.

After the test seal is installed in the seal cartridge, inner and outer filler rings can be installed on either side of the seal. This may be done to minimize the volume of air in the cavities upstream and downstream of the test seal during pressure decay leakage testing. The filler rings may be removed if other leakage measurement techniques are employed. The sizes of these rings are selected based on the outer diameter, width, and thickness of the test seal. 

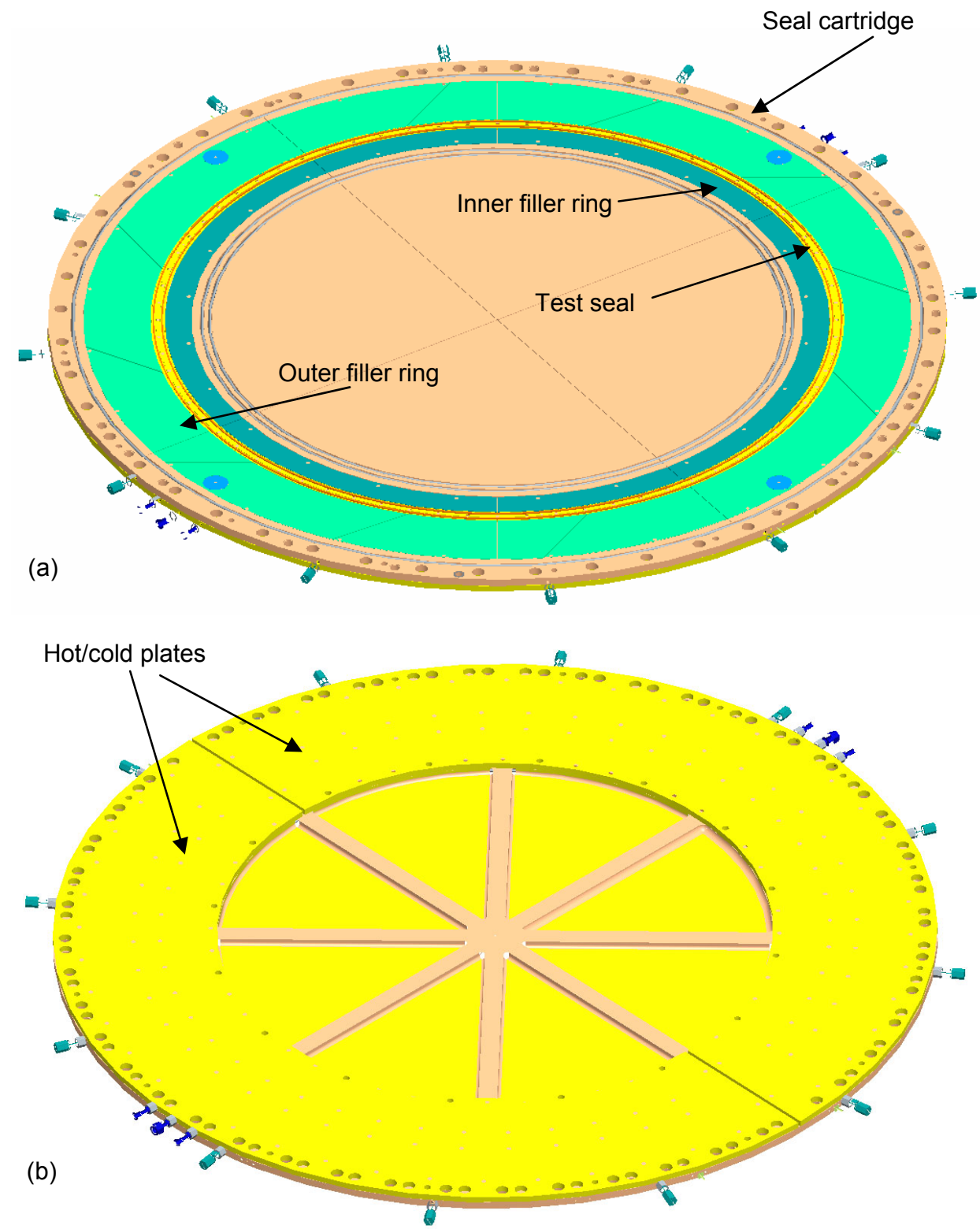

Figure 11.-Top (a) and bottom (b) views of seal plate assembly showing main components.

\section{Seal-on-Seal Versus Seal-on-Plate Testing}

The modular nature of the seal cartridge allows both seal-on-seal and seal-on-plate tests to be performed. For seal-on-seal testing, identical test seals are installed in the upper and lower seal plate assemblies, and the seals are compressed against each other during a test (Fig. 5(a)).

For seal-on-plate testing (Fig. 5(b)), either seal can be replaced by an aluminum ring with a smooth, flat upper surface and seal grooves on the bottom surface (Fig. 13). For early tests the rings are made of 7075-T6 aluminum, but for future flight qualification tests the rings will be made of 7075-T7511 aluminum since this material will be used for the flight seals. The top surface of each ring is ground to a surface roughness of no greater than $16 \mu$ in. to simulate the surface finish of the bare LIDS flange against which the corresponding main interface seal would seal in a seal-on-plate configuration. The bottom surface of the ring was designed so that the back side could be sealed by one or two metal wire seals or a pair of elastomer O-rings. The metal wire seals would be installed in the pair of grooves closest to the bolt holes, while the O-rings would be installed in the other pair of grooves. It is possible, although unlikely, that both O-rings and metal wires could be installed at the same time during testing. 


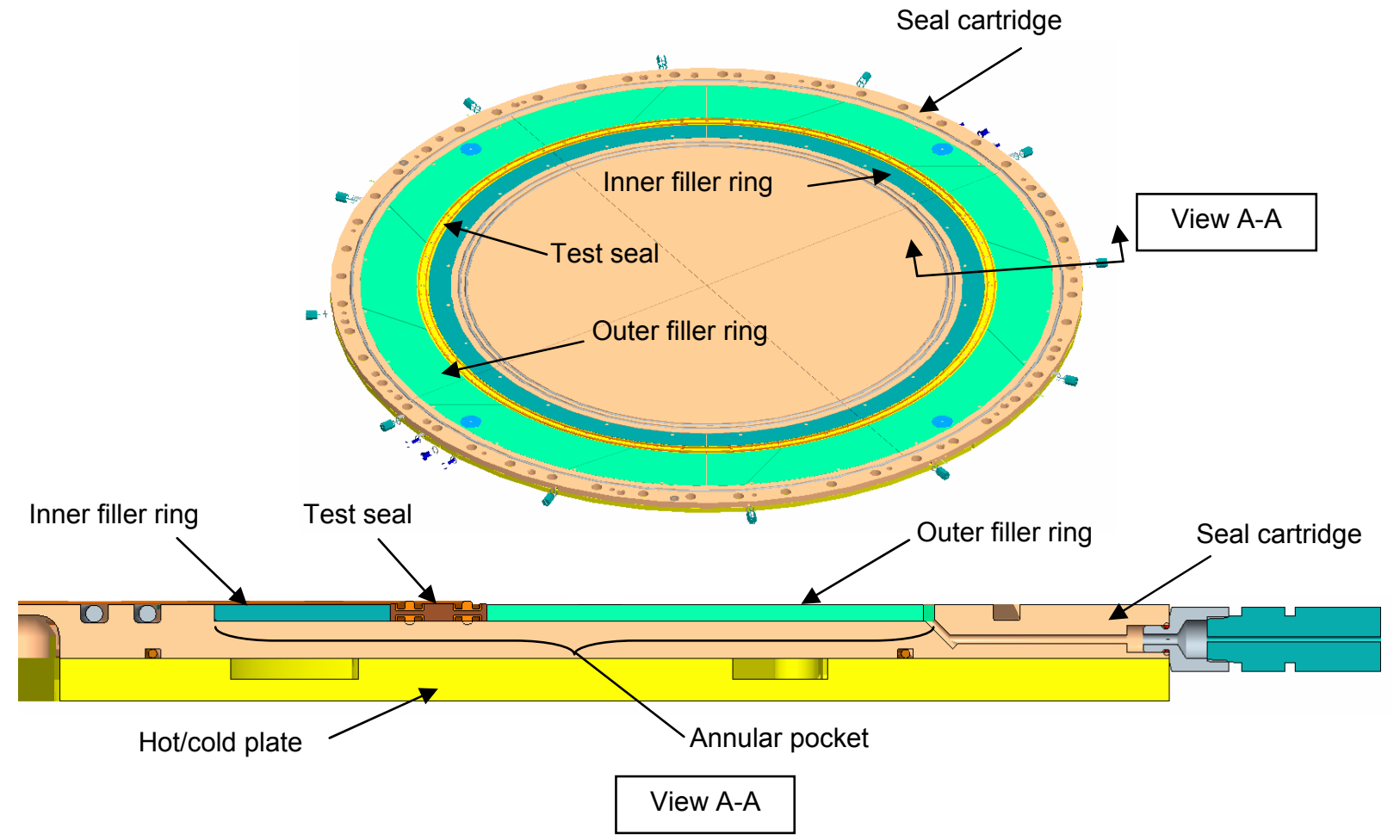

Figure 12.-Cross section of seal plate assembly showing main components.

Flat ring for seal-on-plate testing

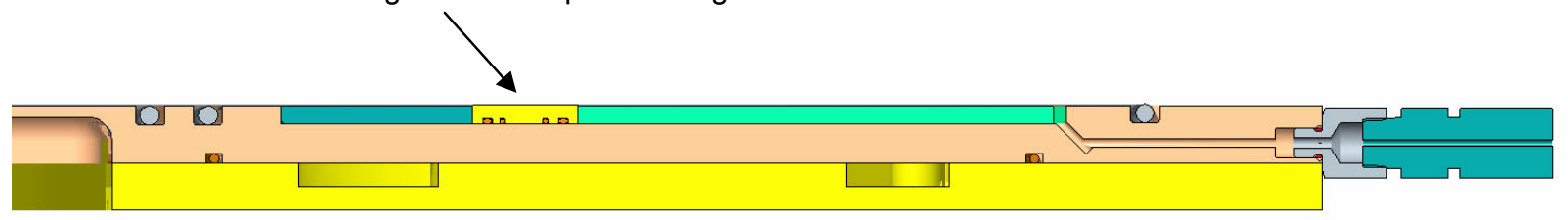

Figure 13.-Cross section of seal plate assembly showing flat ring installed for seal-on-plate testing.

If a LIDS seal-on-plate configuration is implemented during a mission, the "flat plate" condition could be achieved either by installing a flat ring such as the one shown in Fig. 13 or by thickening the LIDS tunnel flange to account for the thickness of the seal. The approach of using either O-rings or metal wire seals on the back side of the flat ring in the test rig allows either condition to be evaluated. If a flat ring is installed on the top of a LIDS tunnel, it may have elastomer seals on the bottom of it. The use of O-rings on the back side of the flat ring in the test rig would simulate this condition. If a thicker LIDS flange is employed instead of a ring, the interface on the back side of the ring would be eliminated as a leakage path. To simulate this condition in the test rig without making a specialpurpose seal cartridge, the leakage through the interface on the back side of the ring must be kept to an absolute minimum. One approach to achieve these extremely low leakage rates is to use indium wire seals on the back side of the ring. Indium wire seals have been successfully used in vacuum applications to form hermetic seals. ${ }^{6}$ The use of indium wire seals on the back side of the ring allows the test rig to simulate the thicker LIDS flange condition during seal-on-plate testing.

To verify the low-leakage performance of the indium wire seals, GRC performed a series of leakage tests on them both in an as-installed condition and after thermal cycling. Indium wires that were $0.10 \mathrm{~cm}(0.040 \mathrm{in}$. $)$ in diameter were cut to length and installed into a groove in a test fixture to form a seal. The groove was $0.11 \mathrm{~cm}$ (0.045 in.) wide and $0.076 \mathrm{~cm}(0.030 \mathrm{in}$.) deep and in the form of a ring with a $1.22 \mathrm{~cm}(0.480 \mathrm{in}$.$) outer diameter.$ The indium wires were installed in the groove such that the ends of the wires overlapped by two wire diameters. During testing the wire seal was compressed against an aluminum plate, and the cavity inboard of the seal was evacuated by the vacuum pump of a helium leak detector. Once vacuum conditions were reached, helium was sprayed around the test fixture, and the helium leak detector was used to check for leakage past the seal. 
The indium wire seal was thermally cycled by sequentially placing the test fixture in liquid baths at various temperatures. A single thermal cycle involved cooling the test fixture to $-60{ }^{\circ} \mathrm{C}\left(-76{ }^{\circ} \mathrm{F}\right)$ in a bath of isopropyl alcohol chilled by crushed dry ice, warming it to room temperature in a water bath, and then heating it to $60{ }^{\circ} \mathrm{C}$ $\left(140{ }^{\circ} \mathrm{F}\right)$ in a separate water bath. The test fixture was subjected to ten thermal cycles before a leakage test was performed. For tests performed on as-installed and thermally cycled indium wire seals, leakage rates of less than $1 \mathrm{x}$ $10^{-8}$ standard $\mathrm{cm}^{3} / \mathrm{s}$ were measured. These leakage rates are orders of magnitude lower than what can be achieved by elastomeric seals demonstrating that indium wires can be used to form near-hermetic seals in the full-scale LIDS seal test rig.

\section{Seal Misalignment/Gapping}

To allow seals to be evaluated in a seal-on-seal configuration under either aligned or misaligned conditions, multiple sets of holes were included near the perimeter of the upper and lower seal cartridges (Fig. 14). Each set is composed of three holes into which precision alignment pins are installed to create various levels of alignment or misalignment. A set of holes was included for the condition in which the top and bottom seals are aligned, and additional sets were included for radial offsets of $0.051,0.102,0.152,0.203,0.254$, and $0.381 \mathrm{~cm}(0.020,0.040$, $0.060,0.080,0.100$, and $0.150 \mathrm{in}$.). The three holes for each alignment condition are located at the same diameter $120^{\circ}$ from one another. Figure 14 shows the pin locations for the aligned and $0.381 \mathrm{~cm}(0.150 \mathrm{in}$.) offset conditions. Pin locations for other offset conditions are located around the perimeter of the seal cartridge in the area in between these two extremes. Offsets become progressively larger as one moves in a clockwise direction from the aligned pin locations to the $0.381 \mathrm{~cm}(0.150 \mathrm{in}$.) offset pin locations. To ensure that the correct sets of holes are used on both the upper and lower seal cartridges for a specific alignment condition, each set of holes was positioned at a different diameter. Every hole pattern in the upper cartridge is coaxial to the centerline of the cartridge. Misalignments between the upper and lower plates are created because the centerline of each hole pattern in the lower cartridge is offset from the centerline of the cartridge by the desired amount of radial offset. Therefore, when the alignment pins are inserted into the appropriate holes in the upper and lower cartridges, the desired amount of offset is achieved.

During a test, three steel alignment pins are inserted into the chosen set of holes in the lower seal plate assembly. To minimize wear in the aluminum seal cartridges, steel bushings are inserted in the holes in the upper cartridge to accept the alignment pins. The upper half of the test rig is then lowered onto the lower half so that the alignment pins in the lower plate slide into the appropriate bushings in the upper plate.

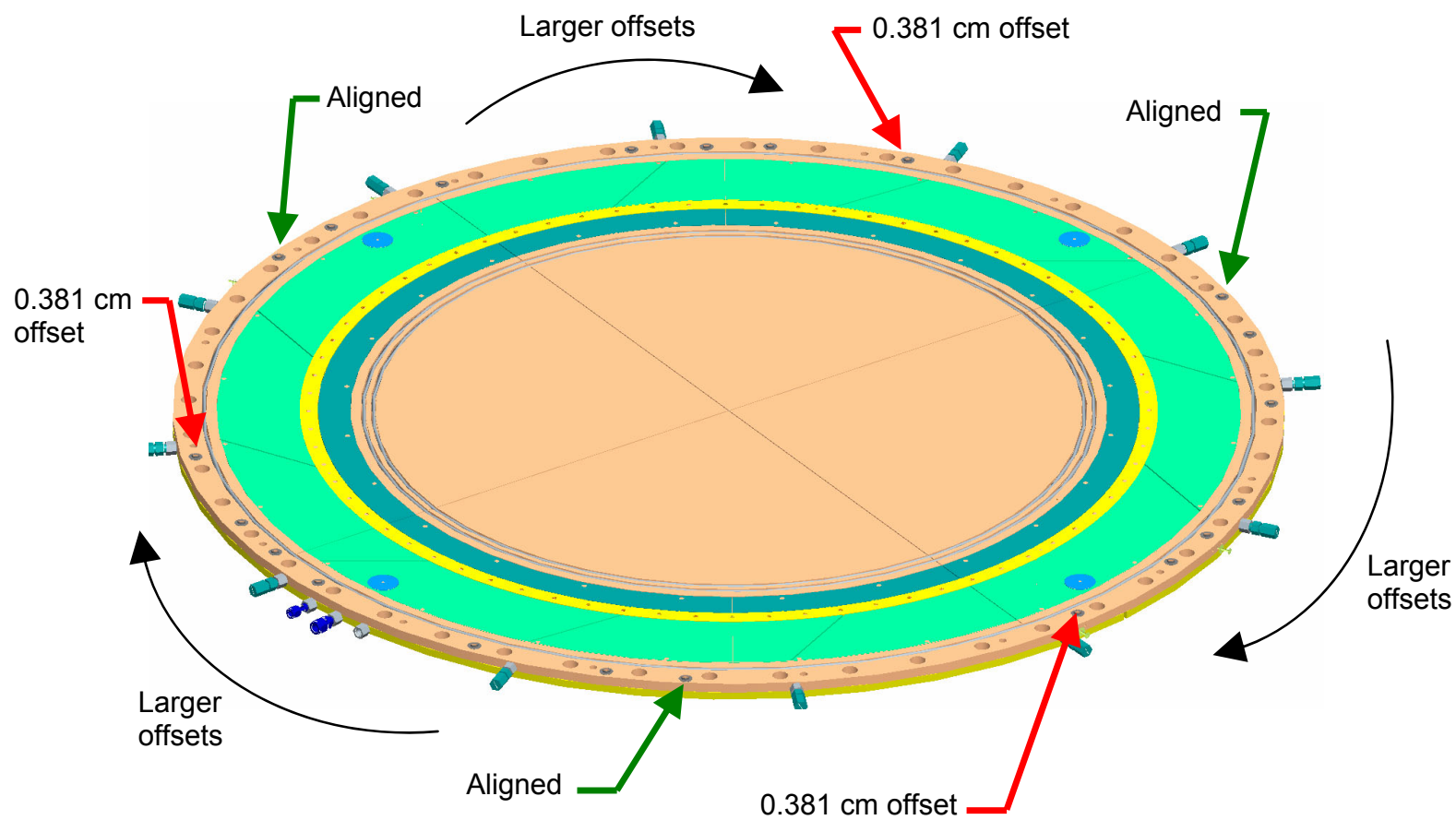

Figure 14.-Alignment pin locations in seal cartridge for aligned (green arrows) and $0.381 \mathrm{~cm}(0.150 \mathrm{in}$.) offset (red arrows) conditions. 
The test rig also allows seals to be tested in fully compressed, angled gap, or uniform gap configurations. The baseline setup for the rig fully compresses the seals by bringing their retainers into metal-to-metal contact. To achieve the angled gap and uniform gap conditions, gapping spacers are installed in the annular pocket of each seal cartridge (Fig. 15). The spacers were located in this area to position them as close as possible to the test seals. The thickness of each spacer is varied to achieve different levels of gapping including $0.025,0.051,0.076$, and $0.10 \mathrm{~cm}$ $(0.010,0.020,0.030$, and $0.040 \mathrm{in}$.) gaps. Oversized O-rings are used outboard of the test seals (Fig. 16) to allow for the $0.10 \mathrm{~cm}(0.040$ in.) gap condition while still maintaining desired pressure conditions. The gapping spacers can be installed in up to four locations that are $90^{\circ}$ from each other to achieve either angled gaps or uniform gaps. Uniform gaps are created by installing spacers of the same thickness in all four locations. Angled gaps are formed by using spacers of different thicknesses at each location. For example, a $0.10 \mathrm{~cm}(0.040 \mathrm{in}$.) angled gap can be created by installing a $0.10-\mathrm{cm}$-thick spacer in one location, $0.051-\mathrm{cm}$-thick spacers in the two locations $90^{\circ}$ away, and no spacer in the location that is $180^{\circ}$ away from the 0.10 -cm-thick spacer.

\section{Pressure Conditions}

The lower seal plate assembly was designed to generate the required pressure differentials across the seals during testing including LIDS operating conditions in space and pre-flight checkout conditions on the ground. This was accomplished by including several ports in the cavities inboard and outboard of the test seals and positioning Orings around those cavities to generate the desired pressure conditions. Figure 16 illustrates how on-orbit pressure conditions are created in the test rig. A port in the center of the lower seal plate assembly provides air at atmospheric pressure (i.e., $101 \mathrm{kPa}(14.7 \mathrm{psia})$ ) to the test rig. Radial spokes cut into the top surface of the seal cartridge allow air to flow to the inner diameter of the test seal. A cross-drilled port in the cavity outboard of the test seal is connected to a vacuum pump to draw the pressure in this region down to vacuum conditions. To facilitate this, the cavity outboard of the test seal is sealed near the perimeter of the seal cartridge by an O-ring. Additional ports or larger ports may be added to this cavity in the future to evacuate this area more quickly.

Pre-flight leakage measurements of the LIDS main interface seals will be made on the ground before a mission to ensure that the seals are installed correctly and operating according to specifications. During these tests, the inner diameter of the seals will be pressurized to $203 \mathrm{kPa}$ (29.4 psia) with ambient pressure around the outer perimeter of the seals to set up the same pressure differential that would be experienced in space. Figure 17 shows how this will be accomplished in the test rig. A cross-drilled port located in the cavity inboard of the test seal provides air at $203 \mathrm{kPa}$ to this region. To prevent the entire cavity inboard of the test seal from being pressurized to $203 \mathrm{kPa}$, a pair of O-rings is positioned just inboard of the port to create an annular region of higher pressure inboard of the test seals. This annular region corresponds to an area in the seal cartridge where the material is thicker to minimize cartridge deflections near the seals. If these O-rings were not included, the area over which the higher pressure is applied would be much larger, and the seal cartridges and fasteners that hold them together would have to be much more robust to resist deformation and operate in a safe manner.

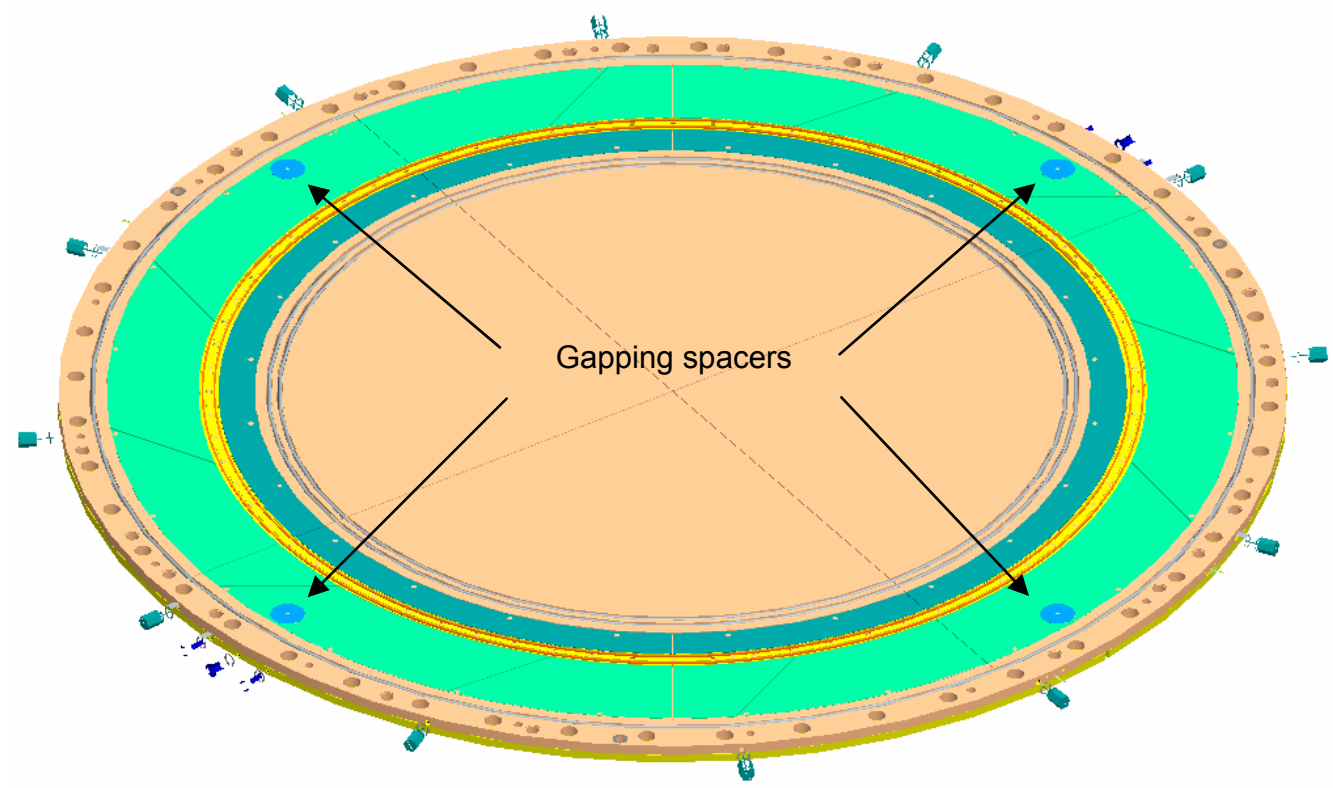

Figure 15.-Gapping spacer locations in seal cartridge. 


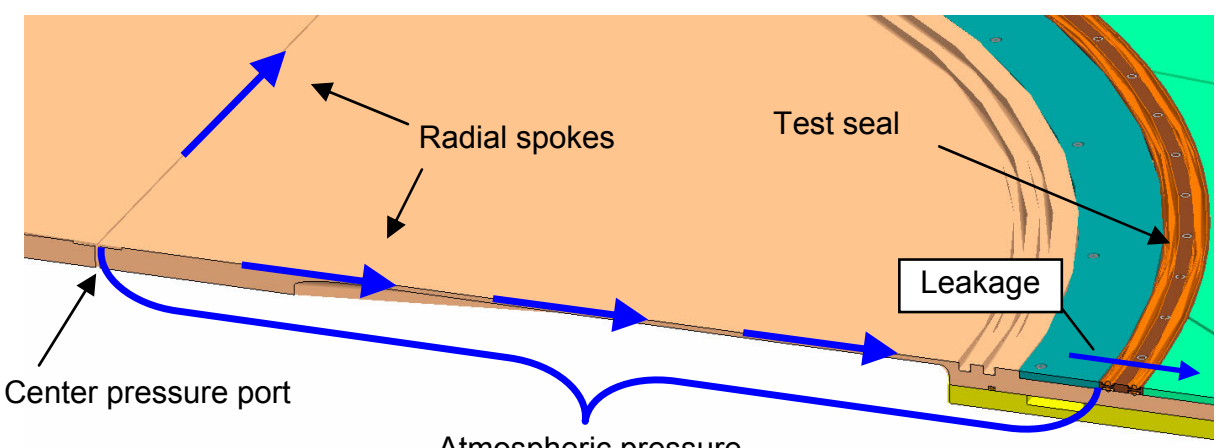

Atmospheric pressure

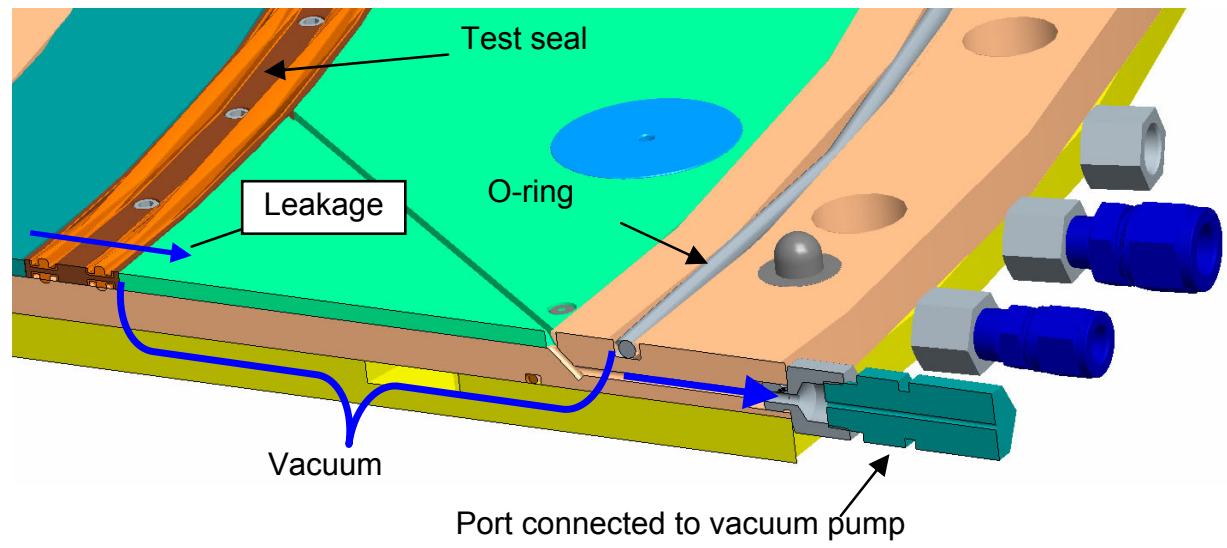

Figure 16.-Cross sections through seal cartridge showing regions of atmospheric pressure (top) and vacuum (bottom) for simulated on-orbit pressure conditions.
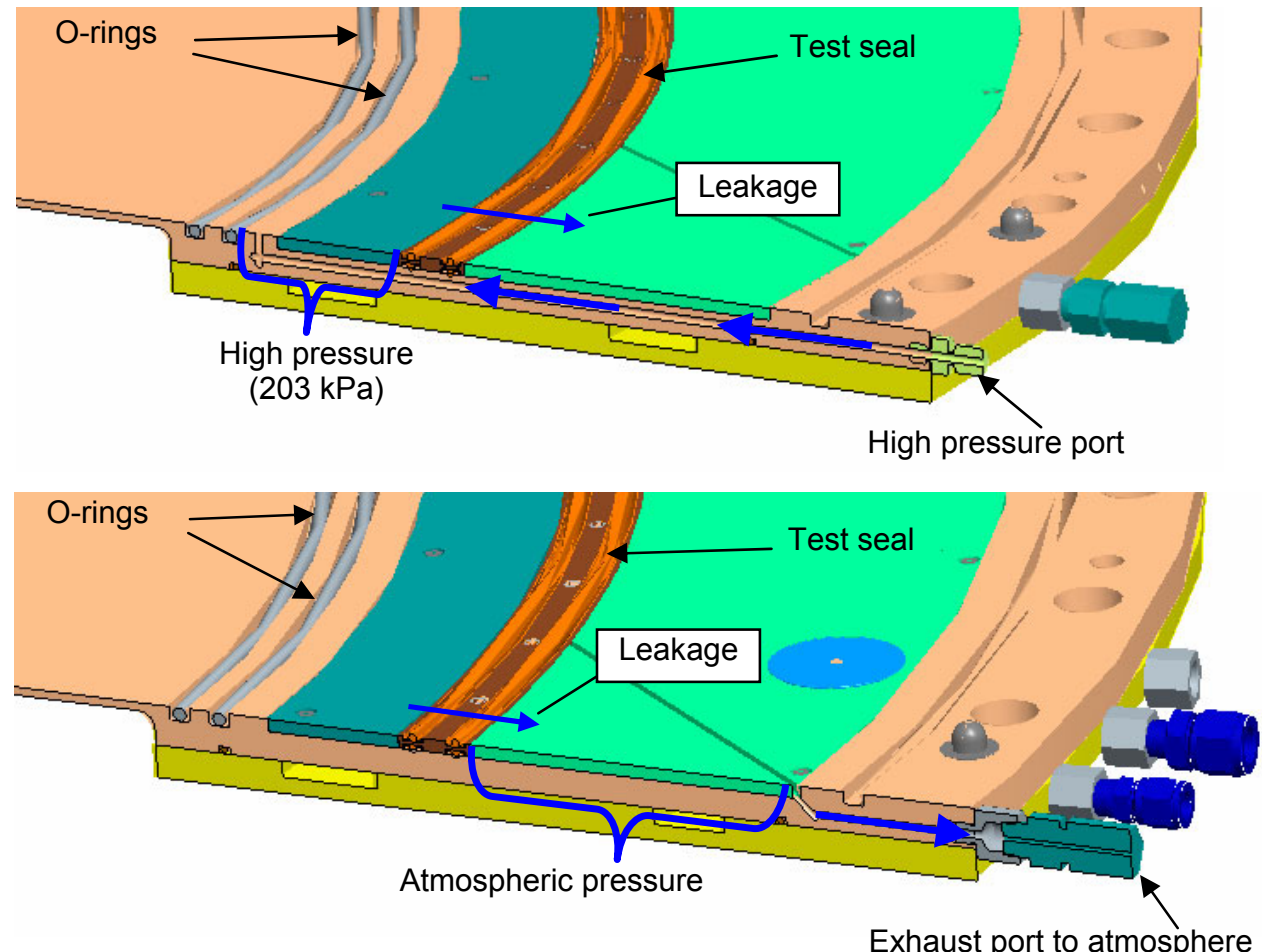

Figure 17.-Cross sections through seal cartridge at different locations showing regions of high pressure (top) and atmospheric pressure (bottom) for pre-flight leakage test pressure conditions. 
With the pressure inboard of the test seals at $203 \mathrm{kPa}$, a pressure differential of $101 \mathrm{kPa}$ (14.7 psid) across the test seals is created by venting the cavity outboard of the seals to atmosphere. This is accomplished by removing the O-ring near the perimeter of the seal cartridge and disconnecting the vacuum pump from the port to which it was connected during on-orbit pressure condition testing.

Note that none of the pressure ports or O-rings in the lower seal cartridge are included in the upper cartridge. This allows the O-rings in the lower seal cartridge to seal against flat metal surfaces on the upper cartridge during testing.

\section{Hot/Cold Plates and Heating/Cooling System}

The final major subsystem of the seal plate assemblies are the hot/cold plates (Fig. 11) designed to heat and cool the seal test specimens to the thermal conditions that they would experience during a mission as described in section II.B.3. To generate the range of temperatures required for these tests, a Two Loop Chiller/Heater, Model 2VLH30W (hereafter referred to as the "chiller") produced by Mydax, Incorporated (Auburn, CA) was selected. This device has a $30 \mathrm{hp}$ compressor and two separate heating/cooling loops that it can control independently over a temperature range of -70 to $60^{\circ} \mathrm{C}\left(-94\right.$ to $140^{\circ} \mathrm{F}$ ). The heat transfer fluid used in both cooling loops is a silicone oil called Syltherm HF produced by The Dow Chemical Company.

The chiller's two separate heating/cooling loops enable it to heat and cool each seal plate assembly independently to achieve the first three required test conditions. Before the chiller was shipped to GRC, the vendor performed a series of checkout tests on a similar unit with a $25 \mathrm{hp}$ compressor it to ensure that it could generate these thermal conditions. For case 2 in which both seals must be cooled to $-50{ }^{\circ} \mathrm{C}$, a constant $4000 \mathrm{~W}$ heating load was applied sequentially to channels 1 and 2 to simulate the thermal loads that the chiller would have to overcome in the test rig. The results of this test are shown in Fig. 18. After the $4000 \mathrm{~W}$ load was applied to channel 1, it took approximately $20 \mathrm{~min}$ for the chiller to cool that loop to $-50{ }^{\circ} \mathrm{C}$. After holding channel 1 at $-50{ }^{\circ} \mathrm{C}$ for $30 \mathrm{~min}$, a $4000 \mathrm{~W}$ load was then applied to channel 2 . While holding channel 1 at $-50{ }^{\circ} \mathrm{C}$, it took approximately 50 min to cool channel 2 to the same temperature. This test proved that a chiller with a $25 \mathrm{hp}$ compressor could generate the desired test conditions for thermal case 2. The chiller that GRC purchased has a more powerful $30 \mathrm{hp}$ compressor that will be able to cool the test rig even more quickly. The vendor also performed checkout tests to simulate cases 1 and 3 with similar success.

The one test condition that drove the configuration of the hot/cold plates the most was the requirement that they be able to heat one half of each seal while cooling the other half (i.e., case 4). In designing the hot/cold plates, it became apparent that this requirement could not be met by a heating or cooling loop that ran in a continuous circle beneath the test seals. Therefore, a design composed of two half rings with a thermal break between them was selected to allow each half of the seal to be heated or cooled independently (Fig. 19).

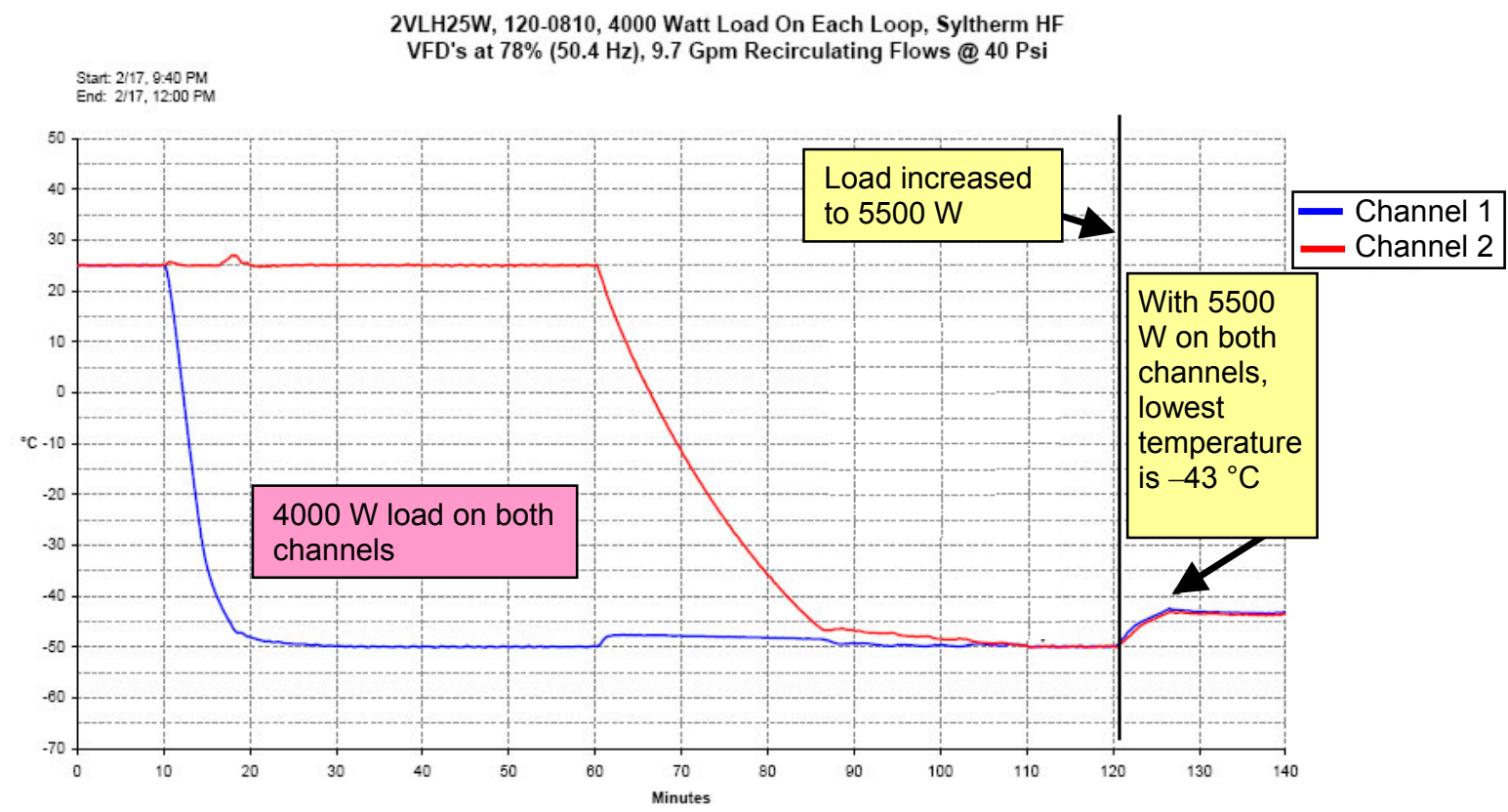

Figure 18.-Results of checkout test on Mydax chiller with $25 \mathrm{hp}$ compressor showing length of time required to cool both loops to $-50{ }^{\circ} \mathrm{C}$ with $4000 \mathrm{~W}$ heating loads applied. 

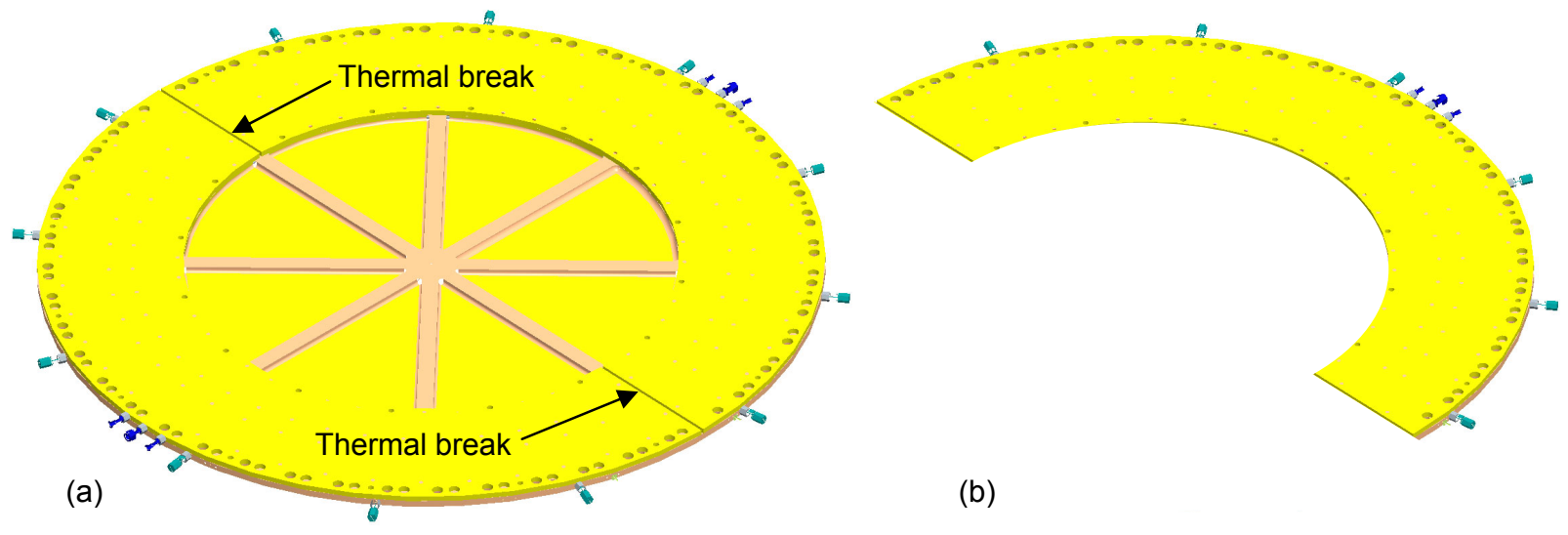

(b)

Figure 19.-Views of hot/cold plates including (a) two plates attached to back side of seal cartridge and (b) bottom view of individual plate.

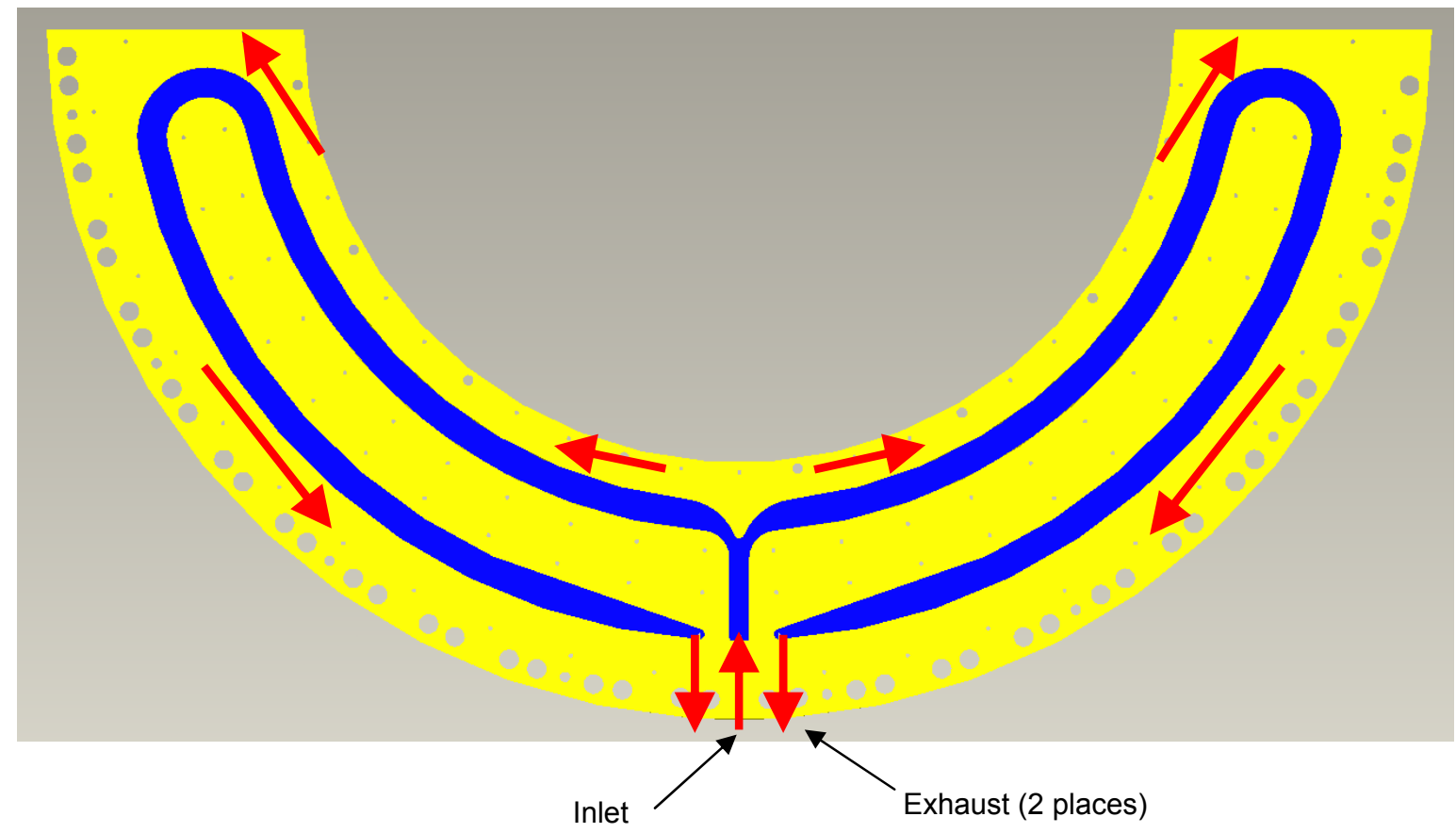

Figure 20.-Top view of hot/cold plate showing layout of fluid passages. Note: red arrows indicate direction of heat transfer fluid flow.

Once the overall configuration of the plates was selected, the layout of the fluid passages in each plate had to be determined. Several different layouts were considered and analyzed, but the final layout that was selected for each hot/cold plate is shown in Fig. 20. In this design, the heat transfer fluid enters though a port near the outer edge of the middle of the plate, flows radially inward toward the inner edge, splits into two symmetric paths that loop out to the ends of the plate, and then flows back along the outer edge to a pair of exhaust ports that return the fluid to the chiller. A fluorosilicone O-ring installed around the perimeter of the fluid passages contains the heat transfer fluid inside this sealed cavity. The final design eliminates the need for a separate cover plate by attaching the hot/cold plates directly to the back side of the seal cartridge to use it as a cover plate. This allows the heat transfer fluid to flow directly against the back side of the seal cartridge to heat and cool the test seals as quickly and efficiently as possible. 


\section{B. Insulator Plate Assemblies}

Separate insulator plate assemblies were designed for both the upper and lower halves of the test rig to insulate both seal plate assemblies during testing (Fig. 10). An epoxy-impregnated fiberglass laminate phenolic material (G10 FR4) was selected as the material for the insulation. This material has a relatively high compressive strength of $448 \mathrm{MPa}(65 \mathrm{ksi})$ allowing it to support the seal clamping loads and low thermal conductivity of $0.288 \mathrm{~W} / \mathrm{m}-\mathrm{K}$

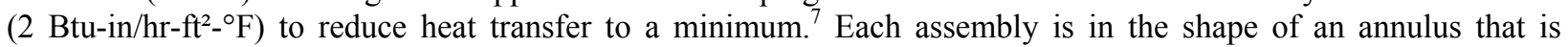
$5.08 \mathrm{~cm}(2.00 \mathrm{in}$.) thick with an inner diameter of $111.76 \mathrm{~cm}(44.00 \mathrm{in}$.$) and an outer diameter of 190.83 \mathrm{~cm}$ (75.13 in.). (Fig. 21) The assembly is composed of eight separate segments that are bonded together using epoxy. Each insulator plate assembly is secured to its respective strongback by 32 fasteners. Also included in the assembly (but not shown in Fig. 21) is a disc of Styrofoam that fits in the open cavity in the center of the assembly to further minimize heat transfer out of the seal plate assemblies.

\section{Strongbacks, Fasteners, and Pedestal}

The upper and lower strongbacks are the main structures of the test rig to which the other assemblies attach. Each strongback is made of 6061-T651 aluminum and is $191.8 \mathrm{~cm}$ (75.50 in.) in diameter and $5.08 \mathrm{~cm}(2.00 \mathrm{in}$.) thick. After the insulator plate assemblies are attached to each strongback, the seal plate assemblies are attached using 32 fasteners per assembly. Belleville washers are installed below the head of each of these fasteners to prevent them from bending excessively as the seal plate assemblies expand and contract during thermal excursions. During testing, the upper and lower halves of the test rig are bolted together using $24 \mathrm{stud} / \mathrm{nut}$ assemblies around the perimeter of the strongbacks. Each stud/nut assembly consists of one 3/4-10 UNC 3A stud and two nuts. Spherical washers are installed below the nuts to accommodate joint rotations that will occur during testing under angled gap conditions. Although only $24 \mathrm{stud} / \mathrm{nut}$ assemblies are required to resist the pressures generated inside the rig during pre-flight checkout condition leakage tests, 48 holes were included in the strongback in case additional fasteners are required for future testing

The lower half of the test rig is installed on a pedestal that is secured to the floor of the test cell. The pedestal is $91 \mathrm{~cm}(36$ in.) high.

\section{Gantry Crane/Hoist}

The upper and lower halves of the test rig are too heavy to be lifted and moved by hand, so provisions were included in the sides of the strongbacks for lifting eyes to be attached. This allows these large assemblies to be lifted by a hoist attached to an overhead gantry crane so they can be positioned during testing or moved around inside the test cell. Once the lower half of the test rig is attached to the pedestal, it will not be moved very frequently. However, the upper half of the test rig must be separated from the lower half every time new test seals are to be installed or when test conditions are changed. To install a new test seal in the upper seal plate assembly, the upper half of the test rig must be lifted above the lower half, rotated $180^{\circ}$ so that the seal is easily accessible, and then
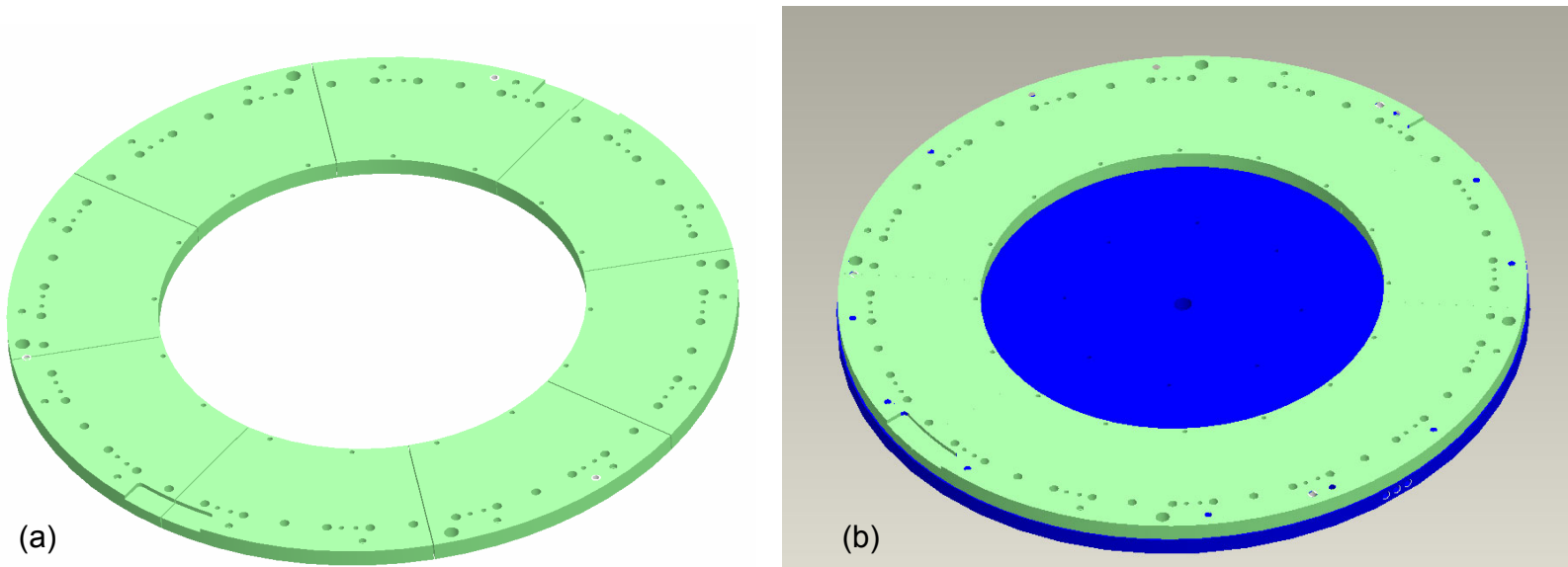

Figure 21.-Views of insulator plate assembly showing (a) eight separate segments bonded together and (b) assembly attached to strongback. 
lowered onto a separate table in the room. This allows test engineers to change out the test seals without having to work underneath the heavy upper half of the test rig. The gantry crane and hoist allow this to be done in a safe, efficient manner.

\section{E. Humidity Enclosure}

Because the test rig must be capable of performing tests at temperatures as low as $-50{ }^{\circ} \mathrm{C}$, condensation and ice would build up on the test hardware when testing at cold temperatures if left unchecked. Excessive ice could prevent seal flanges from closing properly, and the ice could damage the test seals. To prevent this from happening, a special enclosure has been designed to fit around the test rig. This enclosure has loosely sealed walls and a port into which dry air is supplied from compressed air "K"-bottles. Before a test begins, dry air at a very slight positive pressure is allowed to flow into the enclosure. Since it is heavier than moist air, the dry air displaces the humid air from the enclosure by forcing it out through narrow passages where the walls of the enclosure meet. Once the humidity has been displaced from around the test hardware, a test can begin without condensation or ice forming.

\section{F. Instrumentation}

Seal temperatures, pressure differentials across the test seals, and seal leakage are all recorded during testing. Seal temperatures are measured by 12 type $\mathrm{T}$ thermocouples $(0.75 \%$ accuracy $)$ in each seal cartridge. The thermocouples are located $30^{\circ}$ from one another to measure the temperature distribution around the perimeter of the seals during a test. An additional type T thermocouple is used to measure the air temperature in the test cell.

Pressure transducers are located both inboard and outboard of the test seals to measure the pressure differential across the seals during testing. Two of these transducers monitor the high pressure side of the seal and are rated for pressures of 0 to $241 \mathrm{kPa}$ ( 0 to $35 \mathrm{psia})$ with an accuracy of $\pm 1.25 \%$ of full scale. This allows them to measure pressures near $101 \mathrm{kPa}$ (14.7 psia) for the on-orbit pressure condition or $203 \mathrm{kPa}$ (29.4 psia) for the pre-flight leakage test condition. The other two devices are vacuum transducers (accuracy of \pm 5 to $10 \%$ of reading) that measure the pressure on the vacuum side of the seals. A barometric pressure transducer (accuracy of $\pm 0.015 \mathrm{inHg}$ ) is used to measure the atmospheric pressure in the test cell during testing.

Seal leakage measurements can be made in several ways. Room temperature leakage measurements can be made using a pressure decay approach described in detail by Daniels, et al. ${ }^{8} \mathrm{~A}$ commercially available helium leak detector is also being evaluated for leakage measurements at conditions other than room temperature.

Health monitoring instrumentation is also included on the test rig. A type $\mathrm{T}$ thermocouple is located in the humidity enclosure to measure the air temperature inside that chamber, and a pressure gauge rated for 0 to $689 \mathrm{kPa}$ ( 0 to $100 \mathrm{psig}$ ) is used to measure the water pressure of the cooling line leading to the chiller.

\section{Analysis}

\section{A. Hot/Cold Plate Analyses}

\section{Thermal Analyses}

To help guide the design of the hot/cold plates, a series of thermal analyses was performed to ensure that the required thermal test conditions could be achieved. A simplified three-dimensional model of one half of the test fixture (e.g., bottom half) was created in ANSYS including a seal plate assembly, an insulator plate assembly, and a strongback. Three thermal cases were evaluated: both halves of the seal cooled, both halves heated, and the maximum thermal gradient across the seal. The model was oriented vertically for these analyses, and the following boundary conditions were applied:

- The strongback temperature was fixed at $25^{\circ} \mathrm{C}\left(77^{\circ} \mathrm{F}\right)$.

- The convective heat transfer coefficient for the heat transfer fluid inside the hot $/$ cold plates was $394 \mathrm{~W} / \mathrm{m}^{2}-{ }^{\circ} \mathrm{C}$ at $-50{ }^{\circ} \mathrm{C}$. This value was calculated using MacroFlow Version 2.8 (Innovative Research, Inc., Plymouth, $\mathrm{MN}$ ), a system-level computer software package used for the analysis of flow networks.

- The convective heat transfer coefficient for the heat transfer fluid inside the plates was $812 \mathrm{~W} / \mathrm{m}^{2}-{ }^{\circ} \mathrm{C}$ at $50^{\circ} \mathrm{C}$. This was also calculated using MacroFlow. 
- The convective heat transfer coefficient for air passing over the front face of the plates was $5.6 \mathrm{~W} / \mathrm{m}^{2}-{ }^{\circ} \mathrm{C}$ at $0^{\circ}$, and the value for air passing over the edges of the plates was $5.4 \mathrm{~W} / \mathrm{m}^{2}-{ }^{\circ} \mathrm{C}$ at $0{ }^{\circ} \mathrm{C}$. These values were calculated using the empirical relation for free convection from a horizontal cylinder. ${ }^{9}$

The results for all three cases are shown in Fig. 22. Figure 22(a) and (b) show that the chiller can cool and heat the seal plate assemblies to uniform temperatures of $-50{ }^{\circ} \mathrm{C}$ or less and $50{ }^{\circ} \mathrm{C}$ or more, respectively. An additional requirement for the test rig was that it must be able to generate a temperature gradient around the circumference of the test seals of at least $16{ }^{\circ} \mathrm{C}\left(29^{\circ} \mathrm{F}\right)$. Figure 22(c) shows that the hot/cold plate design is capable of creating a temperature gradient as large as $93{ }^{\circ} \mathrm{C}\left(167^{\circ} \mathrm{F}\right)$ from one side of the test seal to the other thereby easily meeting this requirement. The results of these analyses show that the hot/cold plates and chiller are capable of achieving the desired thermal test conditions.

\section{Structural Analyses}

In addition to the thermal analyses that were performed on the hot/cold plates, structural analyses were performed to determine the deflections and stresses that occur in them due to the pressure from the heat transfer fluid. These assemblies are sealed pressure vessels, so hydrostatic pressure tests must be performed on them to certify them for use in the test rig. The pressure applied for the hydrostatic test is based on the maximum allowable working pressure (MAWP), the material properties, and the operating temperature. The following formula was used to calculate the pressure for the hydrostatic test: ${ }^{10}$

$$
\mathrm{P}_{\text {test }}=1.5 \times(\mathrm{MAWP}) \times\left(\mathrm{F}_{\text {ty }} \text { (test temperature) } / \mathrm{F}_{\text {ty } \text { (operating temperature })}\right)
$$

where:

$\mathrm{P}_{\text {test }}=$ hydrostatic test pressure, $\mathrm{kPa}$ (psig)

MAWP = maximum allowable working pressure, $\mathrm{kPa}$ (psig)

$\mathrm{F}_{\mathrm{ty}}$ (test temperature) $=$ material yield strength at temperature at which hydrostatic test is performed, MPa (ksi)

$\mathrm{F}_{\mathrm{ty}}$ (operating temperature) $=$ material yield strength at operating temperature of hot/cold plates, $\mathrm{MPa}(\mathrm{ksi})$

The MAWP for the hot/cold plates is $310 \mathrm{kPa}$ (45 psig). The maximum expected operating temperature is $150{ }^{\circ} \mathrm{C}\left(302^{\circ} \mathrm{F}\right)$, and the hydrostatic test will be performed at $20^{\circ} \mathrm{C}\left(68^{\circ} \mathrm{F}\right)$. An operating temperature of $150{ }^{\circ} \mathrm{C}$ was selected to provide thermal margin to the test rig. The yield strengths for 6061-T651 aluminum at these temperatures are $200 \mathrm{MPa}(29 \mathrm{ksi})$ and $241 \mathrm{MPa}(35 \mathrm{ksi})$, respectively. ${ }^{11}$ Inputting these values into Eq. (1) yields a hydrostatic test pressure of $558 \mathrm{kPa}(81 \mathrm{psig})$.

A finite element model of one of the hot/cold plates was created in ANSYS® Classic, Release 10.0 (ANSYS, Inc., Canonsburg, PA), and a pressure load of $558 \mathrm{kPa}$ psig was applied to the kidney-shaped region inboard of the O-ring seal. The plate was fixed in the $\mathrm{X}, \mathrm{Y} \& \mathrm{Z}$ directions at 85 locations representing the 85 bolts that attach it to the seal cartridge. Figure 23 shows the deflections in the plate under the pressure load. The maximum deflection of $0.011 \mathrm{~cm}(0.0044 \mathrm{in}$.) occurs at the 9 o'clock position near the edge of the left branch of the fluid passage in the plate. Von Mises stresses in the plate were quite low compared to the yield strength of the material with the majority of the plate at $41 \mathrm{MPa}(6 \mathrm{ksi})$ or less.

The heat transfer fluid will also be in contact with the back side of the seal cartridge, so a finite element model of that component was also created in ANSYS and analyzed. The cartridge was fixed in the X, Y \& Z directions at 170 locations representing the 170 bolts that attach the hot/cold plates to the cartridge. The same pressure load of $558 \mathrm{kPa}$ was used, but in this case it was applied to two kidney-shaped regions where the two hot/cold plates would be attached. Figure 24 shows the deflections in the seal cartridge under the hydrostatic pressure load. The predicted maximum deflection of $0.005 \mathrm{~cm}$ (0.002 in.) occurs near the outer circumference of the plate at the 6 o'clock and 12 o'clock positions. These locations correspond to regions where a bolt hole was omitted from the pattern to allow for cross-drilled holes where the fluid enters and exits the sealed cavity. As with the hot/cold plate, von Mises stresses were predicted to be very low with most of the cartridge being very lightly stressed at less than $21 \mathrm{MPa}(3 \mathrm{ksi})$.

The deflections and stresses in the hot/cold plate and seal cartridge were predicted to be quite low when the hydrostatic test pressure was applied to them. The results of these analyses verify that the seal plate assemblies will be able to withstand the pressure imparted on them during testing. 


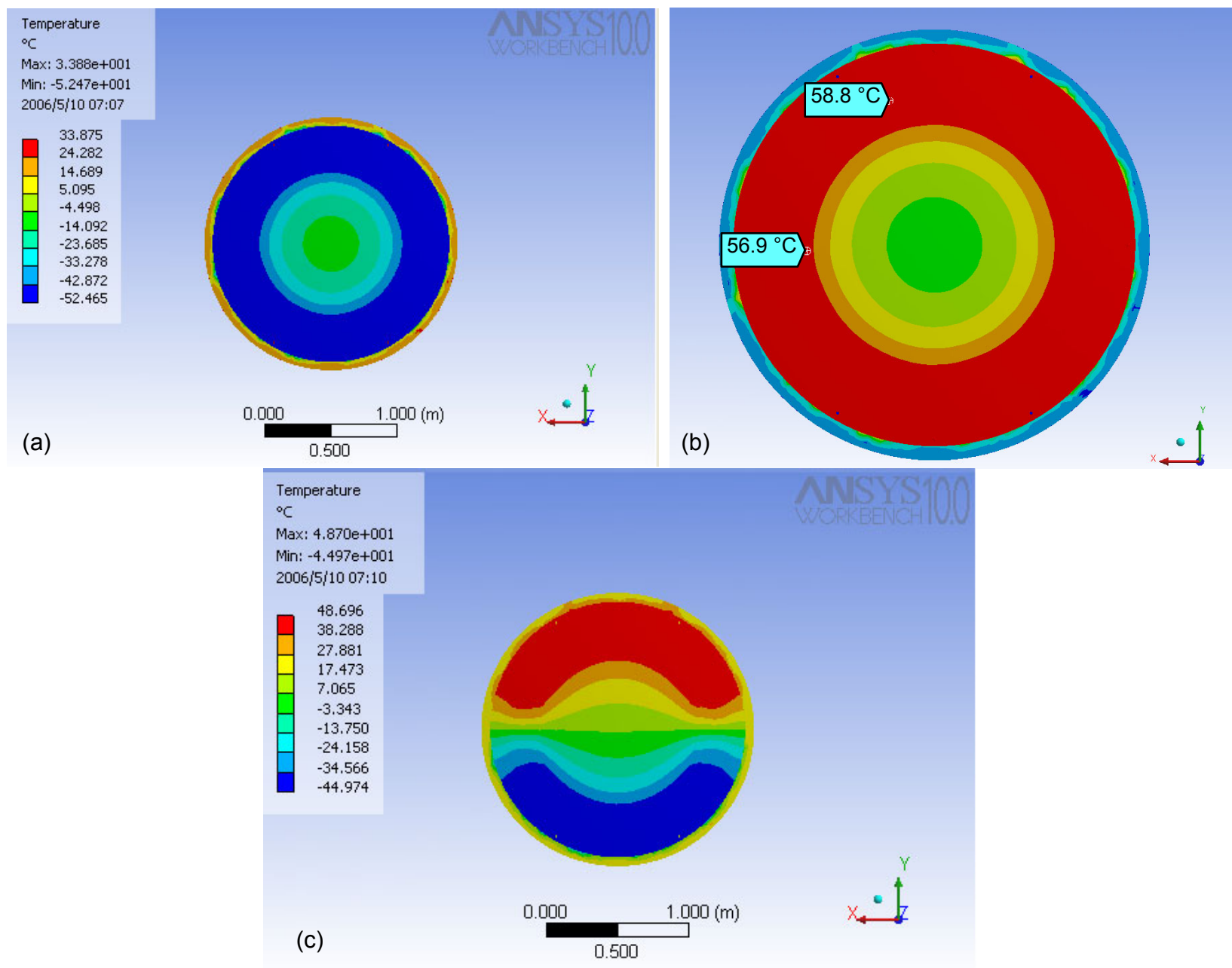

Figure 22.-Temperature distribution across seal plate assembly for three thermal cases: (a) both halves of seal cooled, (b) both halves of seal heated, and (c) maximum thermal gradient across seal.

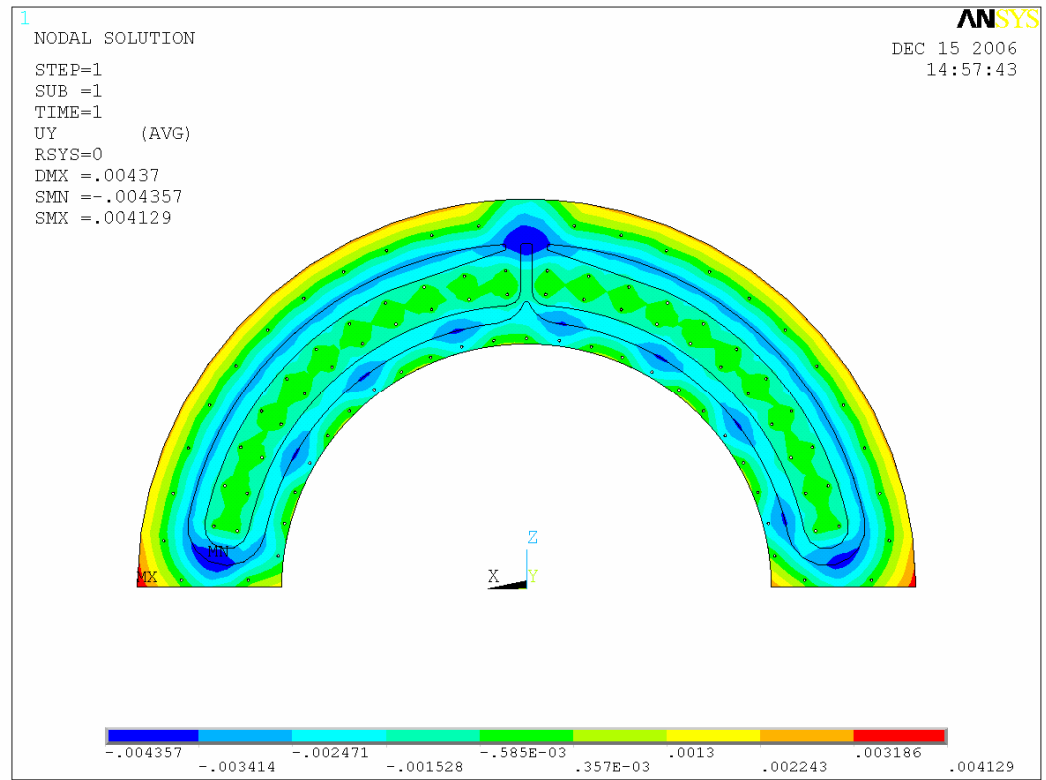

Figure 23.-Deflections (in inches) in hot/cold plate under hydrostatic test pressure conditions. 


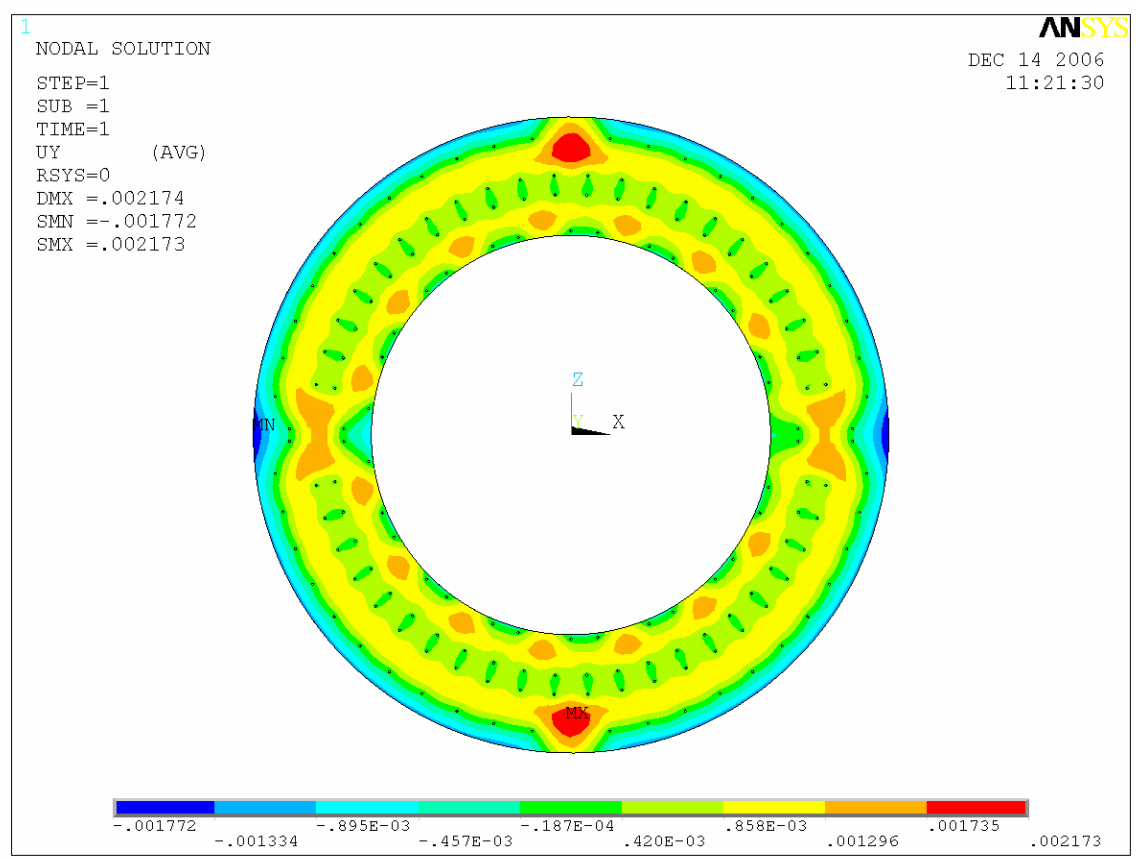

Figure 24.-Deflections (in inches) in seal cartridge under hydrostatic test pressure conditions.

\section{B. Mounting Stud Sizing Analyses}

A circle of fasteners around the perimeter of each strongback is used to bolt the upper and lower halves of the test rig together during testing (Fig. 10). For tests performed using on-orbit pressure conditions, these fasteners may not be needed because the vacuum conditions between the two seal cartridges would tend to pull them together. However, tests performed using pre-flight leakage test pressure conditions must utilize these fasteners to hold the test rig together.

The steps taken to determine the size and quantity of fasteners that are required are shown in the flow chart in Fig. 25. The first step was to determine the amount of clamping load that the fasteners must provide. Including loads generated by the test seals, O-rings, and pre-flight checkout pressure, the total clamping load that the fasteners must provide was estimated to be $445 \mathrm{kN}(100,000 \mathrm{lb})$. Figure 26 plots the total load capacity for a set of fasteners versus the number of fasteners. The various curves represent candidate fastener sizes. Each curve was generated using the tensile area of the fastener, and a yield strength of $689 \mathrm{MPa}(100 \mathrm{ksi})$ was assumed for the fastener material. The red, horizontal dashed line represents the minimum clamping force of $100,000 \mathrm{lb}(445 \mathrm{kN})$. The green box at the far left of Fig. 25 summarizes the quantities of each fastener size required to generate this clamping force. Note that only three $3 / 4-10$ fasteners are required to generate this force.

Another key requirement for the fasteners is uniformity of clamping. Although three $3 / 4-10$ fasteners are sufficient to achieve the minimum clamping force, this number of fasteners would clearly not provide uniform clamping around a $173 \mathrm{~cm}$ (68 in.) diameter bolt circle. A guideline proposed by Shigley states that bolts should not be spaced more than about ten bolt diameters apart to obtain fairly uniform clamping pressure. ${ }^{12}$ The green box in the center of Fig. 25 lists the quantities of candidate fastener sizes required to meet this guideline.

The choice of fastener size and quantity was governed by other practical considerations including the amount of time that would be required to loosen and tighten the fasteners and the torque capacity of the tools available in the test facility to do this. Another consideration was the desire to mimic the clamping features of the LIDS system. The LIDS hard capture system is currently composed of 12 equally-spaced latches. Therefore, a final fastener quantity that is a multiple of 12 was considered best representative of the latches. 


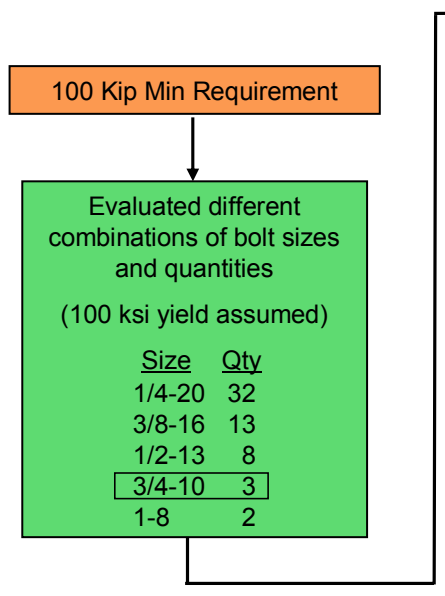

Figure $25 .-$ Flow chart of steps taken to determ
upper and lower halves of test rig together.

\section{Strongback Bolt Load Capacity (Bolt Material $\left.F_{\mathrm{ty}}=\mathbf{1 0 0} \mathrm{ksi}\right)$}

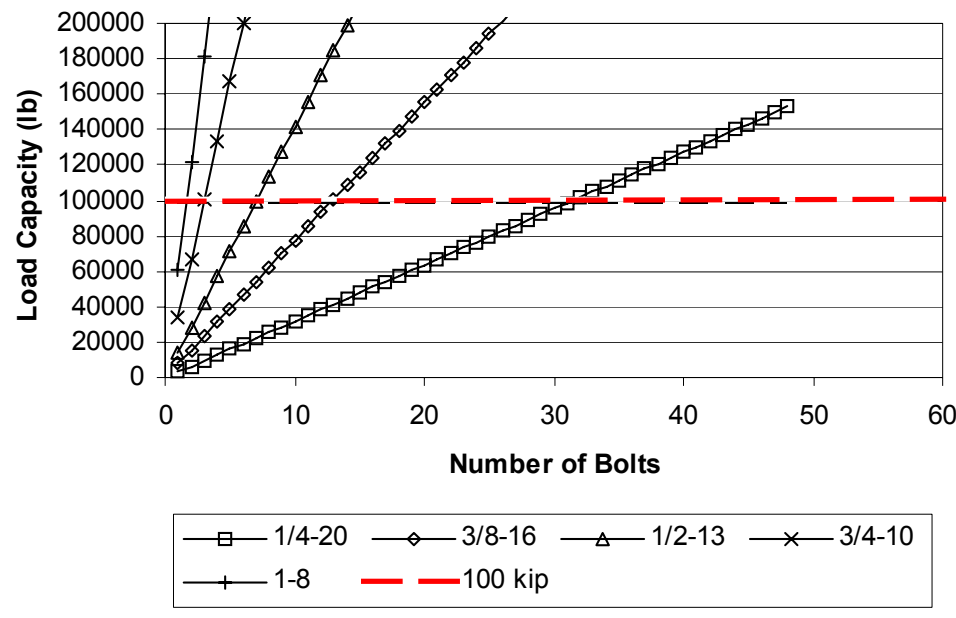

Figure 26.-Plot of total load capacity for a set of fasteners versus number of fasteners. Various curves represent candidate fastener sizes. Red line represents required clamping force of $100,000 \mathrm{lb}$.

To finalize the decision on the size and quantity of fasteners, finite element analyses were performed using ANSYS. A simplified model of the test rig was created, and the $445 \mathrm{kN}(100,000 \mathrm{lb})$ load was distributed across the various regions where it would be applied by the test seals, O-rings, and pressure load. Various fastener quantities were included, and the amount of axial deflection between fasteners was monitored. Figure 27 presents deflection plots for cases in which six and twenty four fasteners were utilized. As seen in this figure, the deflection pattern when six fasteners are used takes on a non-uniform, lobed appearance, whereas the case with twenty four fasteners has a much more uniform deflection pattern. 

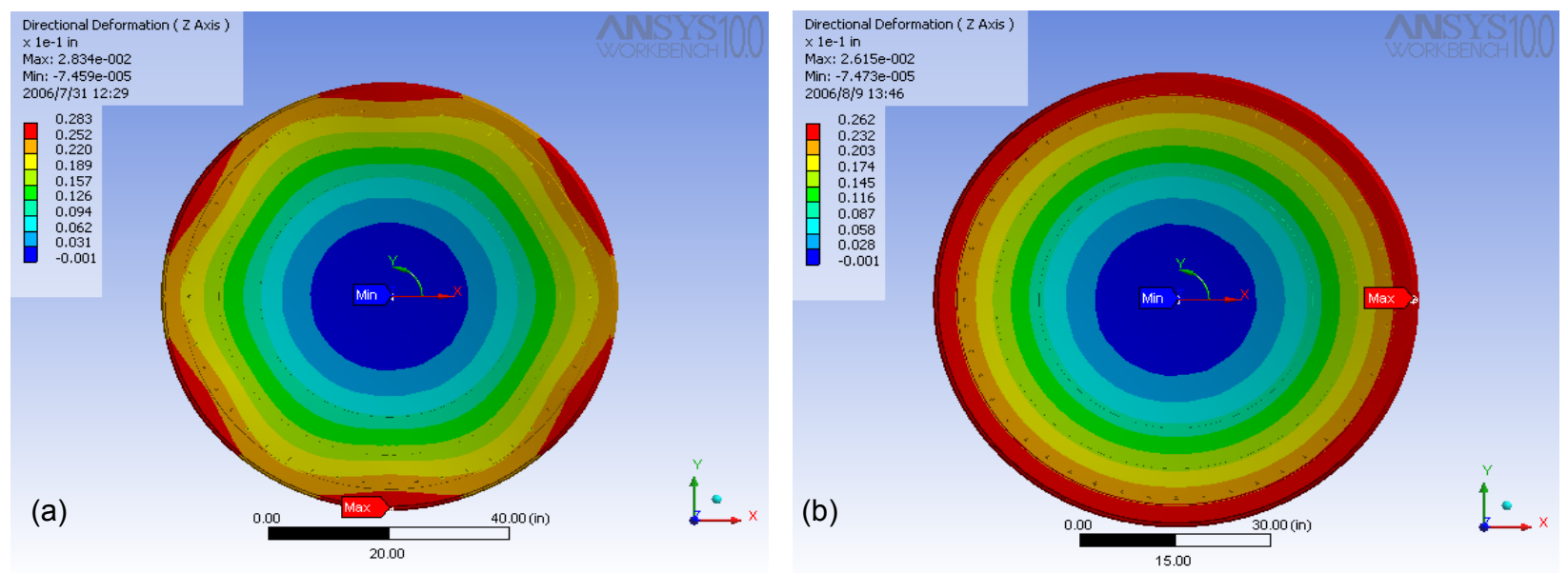

Figure 27.-Deflection plots (in inches) for one half of test rig for (a) six and (b) twenty four fasteners.

Taking into account the results of each type of analysis that was performed, a decision was made to use twenty four $3 / 4-10$ fasteners. The $3 / 4-10$ fasteners are easily able to generate the required $445 \mathrm{kN}$ clamping force, and this force can be applied uniformly over a $173 \mathrm{~cm}$ (68 in.) diameter bolt circle by using twenty four fasteners.

To allow for future growth in the test rig, a total of 48 holes were included in the strongback. These additional holes may be used for tests performed at the largest radial offset conditions of 0.254 and $0.381 \mathrm{~cm}(0.100$ and 0.150 in.). When the rig is set up for these tests, the relatively large $3 / 4-10$ fasteners will not be able to fit through the holes in the offset strongbacks. To enable testing at the larger offsets, smaller 5/8-11 fasteners can be used because their smaller diameters will allow them to fit through the offset holes. Because these fasteners are smaller than the ones originally selected for the rig, more of them will be required. The extra holes in the strongback accommodate the additional fasteners.

\section{Summary}

NASA is developing the LIDS docking and berthing system to support future space exploration missions to lowEarth orbit, the Moon, and Mars. While NASA JSC is responsible for overall development of the LIDS system, advanced technology for the main interface seals for the top of the LIDS tunnel is being developed by NASA GRC. The primary function of these seals is to minimize the leakage through the LIDS-to-LIDS interface when two vehicles mate to ensure that the astronauts have sufficient breathable air for potentially long missions.

GRC has developed a unique test rig to evaluate the leakage of full-scale seals under representative LIDS operating conditions. Modular seal cartridges allow different seal designs to be tested at diameters ranging from 132 to $152 \mathrm{~cm}$ (52 to $60 \mathrm{in}$.). Various seal widths and thicknesses can also be evaluated. The modular cartridges also allow seals to be tested in either a seal-on-seal or seal-on-plate configuration. Sets of alignment pins and gapping spacers are used to test seals in either aligned or misaligned conditions. Gap sizes up to $0.10 \mathrm{~cm}(0.040$ in.) and radial offsets as large as $0.381 \mathrm{~cm}(0.150 \mathrm{in}$.) are possible. Leakage measurements can be made for pressure differentials that the seals will experience on-orbit and during pre-flight leakage testing. Hot/cold plates positioned adjacent to the seals allow each seal to be heated and cooled independently at temperatures from -50 to $50{ }^{\circ} \mathrm{C}$. Thermal gradients across each seal of more than $90^{\circ} \mathrm{C}$ can also be generated. Instrumentation located throughout the test rig provides data on seal performance including leakage rates, pressures, and temperatures.

This one-of-a-kind, full-scale test rig represents a major accomplishment in the LIDS seal development program. It will be an asset both to NASA and the nation to evaluate full-scale seals for the docking system throughout several key phases of the LIDS development project including seal development and qualification for flight. Once LIDS has been implemented on future Exploration missions, the test rig will also be able to assess on-orbit anomalies if needed. 


\section{References}

1“Constellation Architecture Requirements Document (CARD)," Constellation Program document CxP 70000, Release Date December 21, 2006, p. 7.

${ }^{2}$ Lewis, J.L., Carroll, M.B., Morales, R.H., and Le, T.D., National Aeronautics and Space Administration (U.S. Government), Washington, D.C., “Androgynous, Reconfigurable Closed Loop Feedback Controlled Low Impact Docking System with Load Sensing Electromagnetic Capture Ring," U.S. Patent No. 6,354,540, March 12, 2002.

${ }^{3}$ Moyers, W.F., Parker Hannifin Corporation, Cleveland, OH, "Composite Sealing Ring with Compression Stop," U.S. Patent No. 3,195,906, July 20, 1965.

4"C-1 Common Berthing Mechanism System Brief," JSC-36333 Vol. 2, 15 April 2005.

${ }^{5}$ Tong, M., "Low-Impact Docking System (LIDS) Tunnel Thermal Analysis," June 2006.

${ }^{6}$ Lenzen, M. and Collins, R.E., "Hermetic indium metal-to-glass-tube seal," Journal of Vacuum Science \& Technology A: Vacuum, Surfaces, and Films, Vol. 18, No. 2, March 2000, pp. 552-553.

${ }^{7}$ Boedeker Plastics, "NEMA G-10 Fiberglass Epoxy Laminate Sheet," MatWeb Material Property Data [online database], URL: http://www.matweb.com/search/SpecificMaterial.asp?bassnum=PGLAM04 [cited 25 May 2007]

${ }^{8}$ Daniels, C.C., deGroh, H.C., Dunlap, P.D., Finkbeiner, J.R., Steinetz, B.M., Bastrzyk, M.B., Oswald, J.J., Banks, B.A., Dever, J.A., Miller, S.K., and Waters, D.L., "Characteristics of Elastomer Seals Exposed to Space Environments," AIAA-2007-5741, July 2007.

${ }^{9}$ Holman, J.P., Heat Transfer, $9^{\text {th }}$ ed., McGraw-Hill Book Company, New York, 2002, chap. 7, pp. $323-328$.

${ }^{10}$ The American Society of Mechanical Engineers, 2004 Boiler and Pressure Vessel Code, section 8, division 1, 2004.

${ }^{11}$ U.S. Department of Defense, Military Handbook - MIL-HDBK-5H: Metallic Materials and Elements for Aerospace Vehicle Structures, Washington, D.C., 1 December 1998, p. 3-263.

${ }^{12}$ Shigley, J.E., and Mitchell, L.D., Mechanical Engineering Design, $4^{\text {th }}$ ed., McGraw-Hill Book Company, New York, 1983, chap. 8-13, p. 391. 


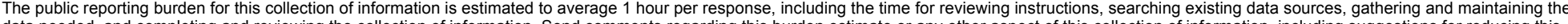

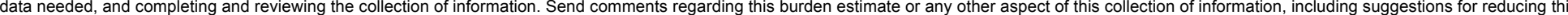

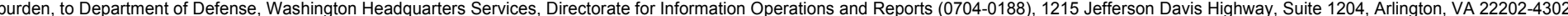

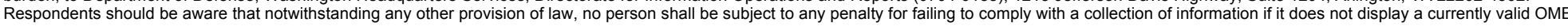
control number.

PLEASE DO NOT RETURN YOUR FORM TO THE ABOVE ADDRESS.

\section{REPORT DATE $(D D-M M-Y Y Y Y)$ \\ 2. REPORT TYPE \\ 3. DATES COVERED (From - To)}

01-10-2007

Technical Memorandum

\section{TITLE AND SUBTITLE}

Full-Scale System for Quantifying Leakage of Docking System Seals for Space Applications

\section{5a. CONTRACT NUMBER}

5b. GRANT NUMBER

5c. PROGRAM ELEMENT NUMBER

\section{AUTHOR(S)}

Dunlap, Patrick, H., Jr.; Daniels, Christopher, C.; Steinetz, Bruce, M.; Erker, Arthur, H.;

Robbie, Malcolm, G.; Wasowski, Janice, L.; Drlik, Gary, J.; Tong, Michael, T.; Penney,

Nicholas

5e. TASK NUMBER

5f. WORK UNIT NUMBER

WBS 644423.06.31.04.01.03.22

\section{PERFORMING ORGANIZATION NAME(S) AND ADDRESS(ES)}

National Aeronautics and Space Administration

\section{PERFORMING ORGANIZATION}

REPORT NUMBER

John H. Glenn Research Center at Lewis Field

E-16218

Cleveland, Ohio 44135-3191

\section{SPONSORING/MONITORING AGENCY NAME(S) AND ADDRESS(ES)}

National Aeronautics and Space Administration

Washington, DC 20546-0001

$\begin{aligned} & \text { 10. SPONSORING/MONITORS } \\ & \text { ACRONYM(S) } \\ & \text { NASA }\end{aligned}$
$\begin{aligned} & \text { 11. SPONSORING/MONITORING } \\ & \text { REPORT NUMBER } \\ & \text { NASA/TM-2007-215024; AIAA-2007- } \\ & 5742\end{aligned}$

\section{DISTRIBUTION/AVAILABILITY STATEMENT}

Unclassified-Unlimited

Subject Category: 37

Available electronically at http://gltrs.grc.nasa.gov

This publication is available from the NASA Center for AeroSpace Information, 301-621-0390

\section{SUPPLEMENTARY NOTES}

\section{ABSTRACT}

NASA is developing a new docking and berthing system to support future space exploration missions to low-Earth orbit, the Moon, and Mars. This mechanism, called the Low Impact Docking System, is designed to connect pressurized space vehicles and structures. NASA Glenn Research Center is playing a key role in developing advanced technology for the main interface seal for this new docking system. The baseline system is designed to have a fully androgynous mating interface, thereby requiring a seal-on-seal configuration when two systems mate. These seals will be approximately $147 \mathrm{~cm}$ (58 in.) in diameter. NASA Glenn has designed and fabricated a new test fixture which will be used to evaluate the leakage of candidate full-scale seals under simulated thermal, vacuum, and engagement conditions. This includes testing under seal-on-seal or seal-on-plate configurations, temperatures from -50 to $50{ }^{\circ} \mathrm{C}\left(-58\right.$ to $\left.122{ }^{\circ} \mathrm{F}\right)$, operational and pre-flight checkout pressure gradients, and vehicle misalignment $( \pm 0.381 \mathrm{~cm}(0.150 \mathrm{in})$.$) and gapping (up to 0.10 \mathrm{~cm}(0.040 \mathrm{in}$.)) conditions. This paper describes the main design features of the test rig and techniques used to overcome some of the design challenges.

\section{SUBJECT TERMS}

Seals; Leakage; Design; Test; Docking; Crew Exploration Vehicle

\begin{tabular}{|c|c|c|c|c|}
\hline 16. SECURI & ASSIFICATION & & 17. LIMITATION OF & 18. NUMBER \\
\hline $\begin{array}{l}\text { a. REPORT } \\
\text { U }\end{array}$ & $\begin{array}{l}\text { b. ABSTRACT } \\
\text { U }\end{array}$ & $\begin{array}{l}\text { c. THIS } \\
\text { PAGE } \\
\text { U }\end{array}$ & UU & $\begin{array}{c}\text { PAGES } \\
31\end{array}$ \\
\hline
\end{tabular}



